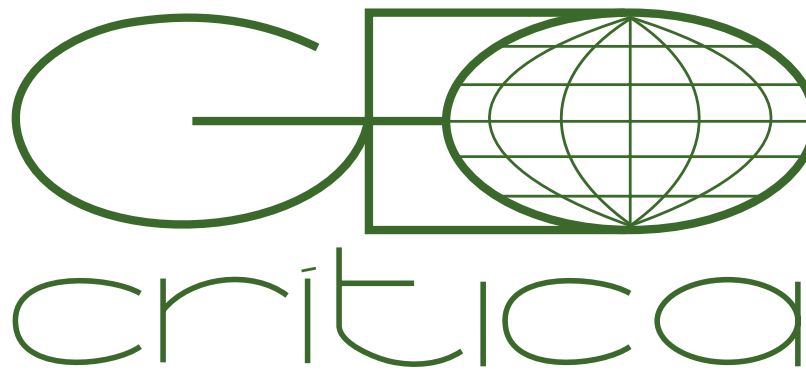

\section{Scripta Nova}

Revista Electrónica de Geografía y Ciencias Sociales Universitat de Barcelona

1 de febrero de 2020

\title{
NATUREZA À VENDA: DA ECOPORNOGRAFIA A UM MODELO COMPREENSIVO DE INDICADORES DE GREENWASHING
}

\author{
Érico L. Pagotto \\ Universidade de São Paulo \\ ericopagotto@usp.br \\ Marcos Bernardino de Carvalho \\ Universidade de São Paulo \\ mbcarvalho@ups.br
}

Recibido: 5 sept 2018; Devuelto para correcciones: 3 junio 2019; Aceptado: 30 julio 2019

\begin{abstract}
Natureza à venda: da ecopornografia a um modelo compreensivo de indicadores de greenwashing (resumo)
\end{abstract}

As propagandas estão presentes hoje em praticamente todos os meios de comunicação, e nelas a recorrência de temas ambientais é cada vez mais notável. Estas chamadas "propagandas ambientais" são elementos importantes em estratégias de marketing que muitas organizações utilizam para demonstrar seu compromisso e suas ações em prol da natureza. Ainda assim, o meio ambiente nunca esteve sob tão forte pressão. Este aparente paradoxo pode ser explicado pela forma como empresas, governos e sociedade põem em curso seu modelo de desenvolvimento civilizatório. Esta reflexão a respeito do greenwashing procura analisar o que há de mentiroso, oportunista e cínico nas propagandas ambientais. Busca também discutir de que forma estes conflitos éticos ajudam a compor um cenário favorável à manutenção de valores culturais insustentáveis que dificultam a mudança para um novo paradigma.

Palavras-chave: propaganda ambiental, meio ambiente, marketing, mudança social.

\section{Nature on sale: from ecopornography to a comprehensive model of greenwashing indicators (abstract)}

Advertising can be found in almost all kinds of media, and among that the increasing occurrence specifically of green advertising is remarkable. This is one of most important strategies organizations has developed to express their commitments and actions for the nature. Although that, the environment has never been under so much pressure. This apparent paradox can be explained according to the way business, government and society articulate themselves to run their model of civilization. This article about "greenwashing" tries to reveal what is misleading, opportunistic and cynical about environmental advertising. It also discusses how these ethical conflicts can forge a favorable scenario to maintain and develop unsustainable cultural values that make a social change for a new paradigm harder to achieve.

Key words: green advertising, environment, marketing, social change. 
Ao longo das cinco últimas décadas a questão ambiental vem percorrendo uma trajetória crescente na pauta das agendas governamentais, do setor privado e do terceiro setor. Muitas organizações ${ }^{1}$, motivadas por fundamentos legais e necessidades mercadológicas, e aproveitando-se da explosão midiática da nova economia, preocupam-se em ocupar espaços publicitários cada vez maiores e mostrar uma postura engajada, capaz de destacá-la num mercado de produtos e selos comoditizados. O greenwashing é um negócio bilionário² com a finalidade de espalhar tinta verde, cooptar o movimento ambientalista, enganar consumidores ${ }^{3}$ e melhorar a performance financeira ${ }^{4} \mathrm{e}$ reputacional ${ }^{5}$ de uma organização.

"Greenwashing" é um termo pejorativo popularizado no início dos anos 90 pelo Greenpeace para descrever uma situação em que se promove uma imagem ambiental positiva que não corresponde à realidade, ou, literalmente, o "ato de enganar consumidores em relação às práticas ambientais de uma companhia ou em relação aos benefícios ambientais de um determinado produto ou serviço" - esta última definição extraída de um site mantido pela ONG especificamente para tratar da questão e orientar sobre o fenômeno, o Stop Greenwash. Etimologicamente, a expressão "green + wash", sem tradução direta ao português, pode ser compreendida como "dar um banho de tinta verde", no sentido de fazer alguma coisa aparentar um falso aspecto "ecológico" ou uma falsa preocupação ambiental.

Diversas outras definições sobre greenwashing têm aparecido na literatura científica, como por exemplo a de Lyon e Maxwell ${ }^{\circ}$, que explicam tratar-se da "apresentação seletiva de informações positivas da performance ambiental ou social de uma empresa sem revelar completamente seus aspectos negativos de forma a criar uma imagem corporativa mais positiva". Mais recentemente alguns autores ${ }^{7}$ têm discutido que se forem consideradas as diferentes formas e contextos em que aparece, pode-se pensar não apenas em uma única definição, mas sim em diversas "variedades de greenwashing".

A prática do greenwashing, no entanto, não é recente. Karliner ${ }^{8}$ apresenta um histórico do conceito. O autor relata que desde a década de 60 um outro termo "ecopornografia" - já se utilizava com o mesmo sentido e de forma a ironizar o oportunismo ou a inconsequência de algumas empresas pelo uso inapropriado de mensagens ambientais em suas propagandas, como por exemplo na imagem abaixo (Figura 1), em que a companhia se orgulhava de "fornecer todos os dias energia suficiente para derreter 7 milhões de toneladas de geleiras".

\footnotetext{
1 Neste trabalho, optamos pela expressão "organizações" para referirmo-nos a instituições privadas, governamentais ou do terceiro setor.

2 Rowell, 2002.

3 Delmas e Burbano, 2011.

4 Lyon e Maxwell, 2011.

5 Munshi e Kurian, 2005.

6 Lyon e Maxwell, 2011.

7 Siano et al., 2017; Lyon e Montgomery, 2015

8 Karliner, 1997.
} 


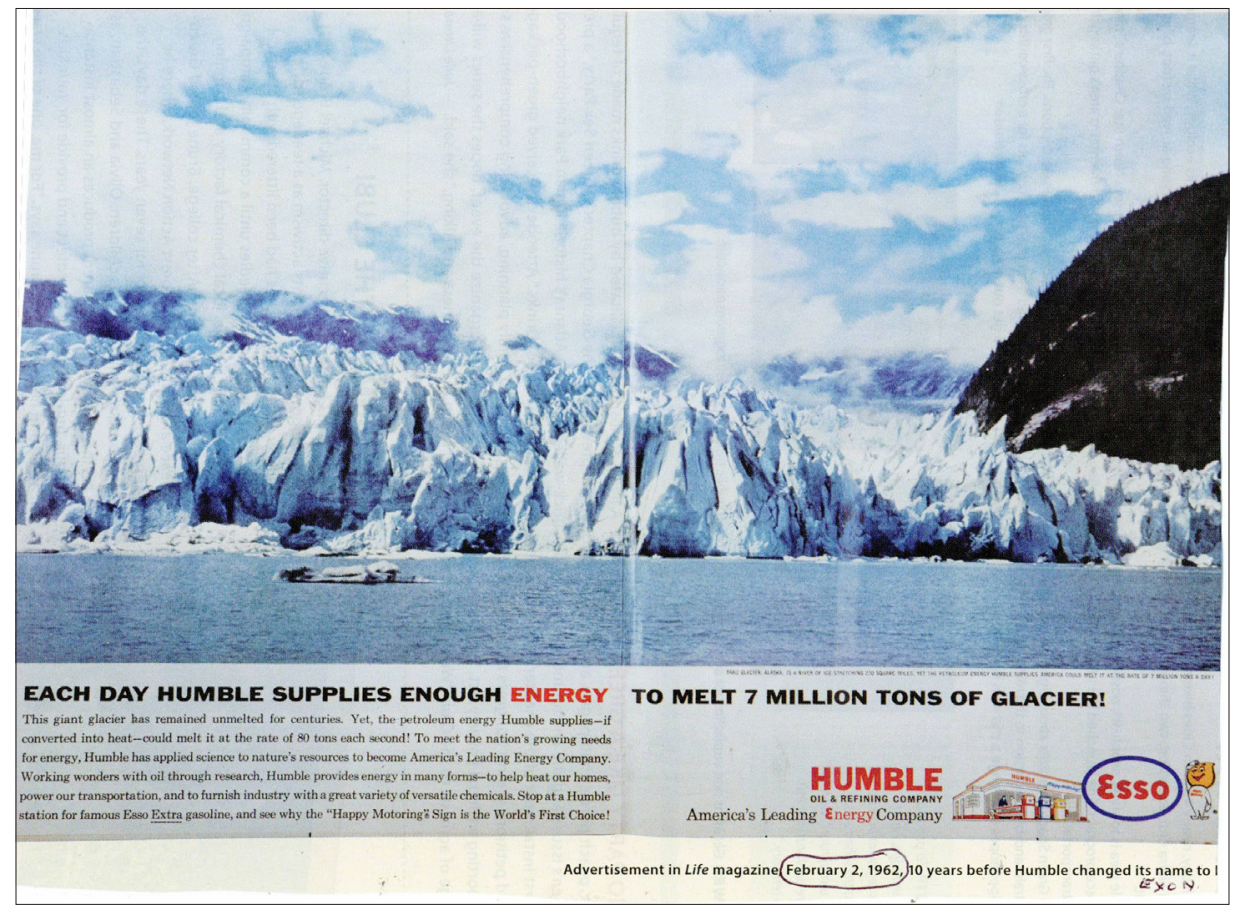

Figura 1: Propaganda da Esso

Publicada em fevereiro de 1962 (Fonte: Life Magazine).

Há diversas definições para ecopornografia. Para alguns autores, ela foi concebida e utilizada para anunciar um produto como "bom para o meio ambiente" ${ }^{\text {, }}$, quando na verdade aspectos não declarados do produto, sua fabricação, distribuição ou descarte tem efeitos reconhecidamente negativos para o meio ambiente (portanto, o mesmo sentido que o greenwashing viria a adquirir a partir da década de 199010). Mais tarde, outros autores passaram a utilizar a expressão "ecopornografia" em um sentido mais estrito, que utilizaremos aqui, associada a discursos ou imagens altamente idealizados ou antropomorfizados de paisagens ou animais não humanos explorados a serviço da produção de bens e de imagens ${ }^{11}$.

Em um mundo essencialmente imagético, esse conceito de "ecopornografia" inspirou-se na ideia usual da pornografia "tradicional", considerando inclusive a crítica que lhe dirigiu o pensamento feminista ${ }^{12}$. Tal conceito abrange manifestações que apelam para um certo romantismo físico-biológico visual de base antropomórfica, que abarca desde imagens bucólicas da natureza, em uma conotação voyeurística de sedução ao mesmo tempo reificada e rejeitada, oferecendo ilusões de beleza e perfeição em uma espécie de "terra-mulher"13, até imagens violentas de desmatamento, dominação ou mortandade de animais como ápice catártico patriarcal, em parte ilustradas nas imagens da figura a seguir (Figura 2) e que veremos repetir-se, mais à frente, em outras figuras e/ou ilustrações aqui trazidas a título de exemplo.

9 No original: “environmental friendly” (Hoch e Franz, 1992).

10 Karliner, 1997; Hoch e Franz, 1992.

11 Conlogue, 2013; Adams, Craimer e Ditmer, 2014.

12 Dobrin e Morey, 2009.

13 Adams, Craimer e Ditmer, 2014. 


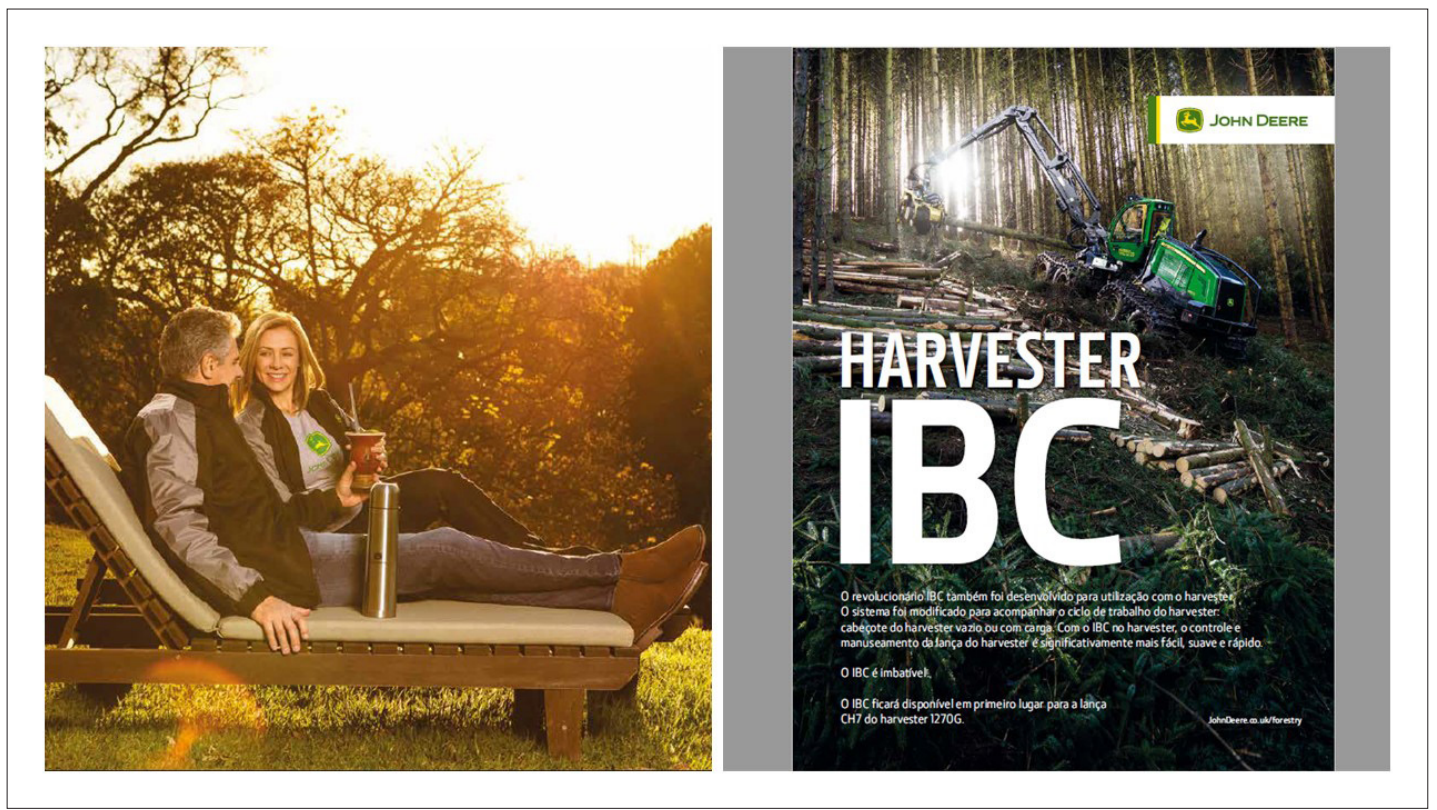

Figura 2: Imagens do catálogo de roupas e máquinas da John Deere Fonte: John Deere, 2018.

Até por volta das décadas de 1980 e 1990, no entanto, a repercussão dessa promiscuidade publicitária era restrita. As empresas de comunicação (imprensa, rádio e televisão) tinham alcance regional limitado. Com os avanços tecnológicos e a mundialização neoliberal, rapidamente a rede midiática foi dominada por sistemas oligopolistas financiados pela propaganda comercial ${ }^{14}$. Nestes sistemas, as empresas atuam em três níveis: internacional, nacional e regional. As que atuam em âmbito internacional detêm maior poder econômico, produzem e distribuem conteúdo para as empresas líderes nacionais, como Prisa (Espanha), Televisa (México) e Globo (Brasil). Estas, por sua vez, atuam em parceria com empresas menores, de âmbito regional, que em troca oferecem capilaridade e desenvoltura política local.

Este tipo de arranjo comercial tem impactos não apenas econômicos, mas sobretudo políticos ${ }^{15}$. Diferentemente de um "livre mercado", trata-se de um sistema coordenado que atua politicamente para assegurar estabilidade e proteção contra interferências do interesse público. A coordenação passa pelo financiamento de agentes políticos (como na indústria do lobby estadunidense), que podem então contar com representantes em diferentes esferas governamentais. O sistema é tanto mais beneficiado quanto mais a classe trabalhadora for despolitizada e entretida com banalidades, sensacionalismo policial, televangelismo ou propagandas. A partir da década de 1990, a publicidade se tornou a nova retórica mundializada do capital $^{16}$, com sua ideologia do progresso, ênfase em tecnologias de produção e responsabilidade socioambiental corporativa como estratégia mercadológica de combate à comoditização e estímulo à confiança e às compras.

14 Butts, 2003.

15 McChesney, 2001.

16 Rocha, 2010. 
O objetivo deste artigo é propor um quadro metateórico de categorias analíticas a partir das quais seja possível caracterizar e analisar as propagandas ambientais quanto à ocorrência de greenwashing, revelando-lhes, em certa medida, seus aspectos "ecopornográficos". Para demonstrar sua viabilidade e aplicação prática, foram selecionadas algumas propagandas ambientais dos setores financeiro e automotivo.

Antes, porém, uma palavra sobre o método que utilizamos para a construção desse "quadro".

\section{Referências e indicadores para detectar greenwashing}

Partindo-se de alguns autores em publicações cientificas especializadas, propomos um quadro de referências teóricas por meio do qual se pode definir e caracterizar a ocorrência do greenwashing, e assim utilizá-lo como guia para análise de propagandas e, consequentemente, para averiguação dos "vários tons de verde" que buscam imprimir às mensagens que divulgam, com o intuito de capitalizar vantagens para seus produtos, serviços ou imagens corporativas.

Para a construção deste quadro de referências, foram selecionadas três obras: a dos estadunidenses Kenny Bruno e Joshua Karliner, a do britânico Ed Gillspie e a do australiano Guy Pearse, que serão apresentadas a seguir.

Kenny Bruno é um reconhecido ativista do Greenpeace que, à época da Eco 92, ajudou a popularizar a expressão "greenwash". Joshua Karliner é um dos fundadores da CorpWatch, uma ONG dedicada ao jornalismo e à pesquisa investigativa de empresas transnacionais. Seu livro, "Earthsummit.Biz"17, traz uma perspectiva crítica sobre a apropriação do discurso ambientalista pelas grandes corporações. O especialista em marketing ambiental Ed Gillspie é um dos fundadores da Futerra, uma empresa de consultoria especializada nesta área e autor de um popular guia sobre o greenwashing ${ }^{18}$. Guy Pearse é professor na Universidade de Queensland, onde se dedica ao estudo de mudanças globais. Em 2012, publicou uma coletânea de propagandas divulgadas na Austrália para discutir a ocorrência de greenwashing de forma amplamente disseminada em mercados como a indústria de alimentos, bancos, carros, energia, moda, transportes, serviços, eletrônicos, entre outros ${ }^{19}$.

Com base nas referências destes três trabalhos, é possível propor um quadro diagnóstico com quatro categorias analíticas do greenwashing - discursividade, estética, ações e portfólio - que, embora apresentados destacadamente, devem ser compreendidos de maneira integrada, e a partir do qual as ações de uma organização podem ser tipificadas (Quadro 1) como veiculadoras de greenwashing. Este quadro, juntamente com os procedimentos metodológicos da análise crítica do discurso ${ }^{20}$, é que deram apoio à interpretação da discursividade das propagandas analisadas mais à frente.

17 Bruno e Karliner, 2002.

18 Gilspie, 2008

19 Pearse, 2012

20 Fairclough e Wodak, 1997. 


\section{Quadro 1: Indicadores característicos de greenwashing segundo diversos autores.}

Bruno e Karliner (2002)

- Imagens sedutoras: associar o nome da empresa ou produto a belas imagens naturais, sem necessariamente fazer alguma alegação, esperando que o consumidor faça a associação por conta própria;

- Desviar a atenção para projetos paralelos: apresentar uma série de investimentos em projetos sociais e ambientais, quando na verdade a maioria deles refere-se ao atendimento de obrigações legais ou meras filantropias assistencialistas de custo marginal;

- Retirar o foco de suas atividades danosas: enaltecer determinados aspectos da produção, tais como: melhorias na segurança laboral, redução de emissões ou economia de energia, que desviam a atenção do público para o fato de que o negócio é, em essência, fortemente degradador ambiental;

- Apropriar-se da linguagem ecológica: utilizar-se indevidamente o jargão técnico para induzir a audiência a crer que estão "salvando o planeta", ao invés de estarem consumindo seus recursos;

- Evitar intervenções externas afirmando que eles resolverão o problema sozinhos: afirmar ter "profundo interesse" na resolução dos problemas ambientais e que está "trabalhando para isto", em alguns casos alegando que determinadas medidas regulatórias teriam um custo demasiadamente alto para ela, procurando atrasar ou esquivar-se da resolução definitiva de problemas.

Gillspie (2008)

- Palavras "meigas": uso de palavras ou expressões clichês, com significado vago;

- Produtos "verdes" lançados por empresas reconhecidamente poluidoras;

- Imagens sugestivas aludindo a um impacto falsamente positivo sobre o ambiente;

- Alegações irrelevantes que superestimam efeitos positivos de um produto ou de algum de seus componentes;

- Afirmações genéricas sobre a empresa ou seu produto ser "o melhor da categoria";

- Atributos ecológicos de alguma linha de produto que, em si, faz mal ao meio ambiente ou às pessoas;

- Jargões técnicos ambientais incompreensíveis aos leigos;

- “Amigos imaginários", referindo-se principalmente à utilização em propagandas de falsos selos ou figuras que imitam certificações;

- $\quad$ Afirmações sem provas ou que não podem ser verificadas;

- $\quad$ Apresentação de dados inverídicos ou falsas alegações.

Pearse (2012)

- Logotipos com vários tons de verde e formas orgânicas; 
- Slogans ambientais com apelo mercadológico;

- Diretores de empresas que atuam como executivos de alguma ONG ambientalista;

- Missões corporativas que enfatizam fortemente o compromisso da empresa com o meio ambiente;

- Lançamento de produtos "verdes", geralmente anunciados por celebridades;

- Websites bastante ativos, geralmente bem ilustrados, mas pouco descritivos, com notícias sobre "avanços" ecotecnológicos;

- Lançamento de "eco-lojas" ou eco-produtos, com uso de estratégias agressivas de comunicação, incluindo multimídia, redes sociais e depoimentos de parceiros comerciais mostrando seus compromissos com o meio ambiente;

- Incentivos aos clientes para contribuírem de forma voluntária com as campanhas da empresa;

- Dicas sobre como levar um estilo de vida mais "verde", incentivos à população para compartilhar suas experiências, dialogar com a empresa e sugerir novas formas para a organização "esverdear" suas atividades;

- Participação e divulgação de eventos de caráter socioambiental produzido por terceiros, principalmente ONGs ambientalistas;

- Montar uma equipe interna de "eco-colaboradores", mantendo-a visível e proativa on e offline.

Fonte: elaboração própria a partir das referências citadas.

A discursividade visa analisar o que a organização manifesta em seu discurso, e o que o dito e não-dito significam no contexto do que foi enunciado e, indo mais além, também "como" este discurso significa, isto é, como produz significados às suas audiências.

A estética está relacionada à forma como a organização se apresenta, e às escolhas imagéticas feitas por ela para representar seu posicionamento mercadológico e institucional.

As categorias das ações compreendem aquilo que a organização faz, a forma como ela se relaciona com os demais stakeholders, e as relações que tais ações guardam com o meio ambiente.

O portfólio compreende o repertório de produtos e serviços que a organização oferece por meio da propaganda, e que eventualmente poderão ser discutidos, isoladamente ou em conjunto, com os demais itens do portfólio mercadológico.

Cumpre observar que o enquadramento nos indicadores de cada categoria analítica visa uma classificação essencialmente qualitativa. Assim, uma única propaganda pode incorrer em apenas uma categoria, ou em várias, e apresentar apenas um de seus indicadores, ou vários. O número de categorias e indicadores que se verifica (ou seja, os "tons de verde") estão relacionados à estratégia de operação do greenwashing por cada empresa.

O Quadro 2, a seguir, apresenta um resumo com os indicadores de greenwashing que podem ser identificados nas propagandas ambientais. 
Quadro 2: Greenwashing segundo categorias analíticas e seus indicadores

\begin{tabular}{|c|c|c|c|}
\hline $\begin{array}{r}\text { CATEGORIAS } \\
\text { ANALÍTICAS }\end{array}$ & INDICADORES & $\begin{array}{c}\text { BRUNO E } \\
\text { KARLINER, } \\
2002\end{array}$ & $\begin{array}{l}\text { GILLSPIE, } \\
\text { 2008c }\end{array}$ \\
\hline
\end{tabular}

1. Manipular o discurso ambientalista com slogans, exageros, afirmações irrelevantes, genéricas ou

X $\quad X \quad X$
pretensões irreais.

2. Mentir, usar dados falsos, fazer afirmações que distorcem a realidade ou que não podem ser provadas.

3. Tratar ganho de performance tecnológica como "investimentos em meio ambiente"

X

4. Utilizar jargão técnico incompreensível.

5. Usar imagens, sons ou vídeos ambientais sedutores.

$\mathrm{X}$

$\mathrm{X}$

$\mathrm{X}$

6. Omitir imagens da operação dos negócios.

\section{X}

7. Destacar parceiros que compartilham compromissos ecológicos.

8. Apresentar falsos selos ou figuras que imitam certificações

X

9. Utilizar uma identidade visual ambientalista.

$\mathrm{X}$

$\mathrm{X}$

X

10. Desviar atenção para projetos socioambientais paralelos.

$\mathrm{X}$

$\mathrm{X}$

11. Tratar obrigações legais como investimentos socioambientais.

$\mathrm{X}$

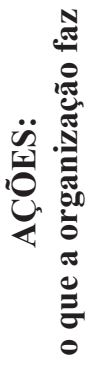

12. Alegar custo excessivo de medidas ecologicamente mais corretas.

$\mathrm{X}$

13. Omitir impactos ambientais negativos da operação de seu negócio, destacando apenas os $\mathrm{X}$ positivos.

14. Evitar intervenções externas alegando que resolverão o problema sozinhos.

$\mathrm{X}$

15. Infiltrar-se na comunidade ambientalista.
$\mathrm{X}$

$\mathrm{X}$

$\mathrm{X}$ 


\begin{tabular}{|c|c|c|c|c|}
\hline $\begin{array}{l}\text { CATEGORIAS } \\
\text { ANALÍTICAS }\end{array}$ & INDICADORES & $\begin{array}{c}\text { BRUNO E } \\
\text { KARLINER, } \\
2002\end{array}$ & $\begin{array}{l}\text { GILLSPIE, } \\
2008 c\end{array}$ & $\begin{array}{c}\text { PEARSE, } \\
2012\end{array}$ \\
\hline 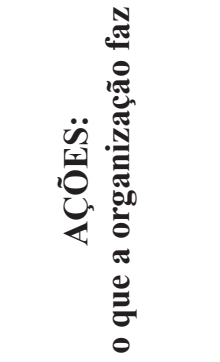 & $\begin{array}{l}\text { 16. Atrasar ou esquivar-se da resolução } \\
\text { definitiva de problemas ambientais. } \\
\text { 17. Incentivar clientes a contribuírem, } \\
\text { e comunicarem-se com a empresa, } \\
\text { estimulando a propositura de novas } \\
\text { formas de ser e de tornar a empresa } \\
\text { mais "verde". }\end{array}$ & $\mathrm{X}$ & & $X$ \\
\hline 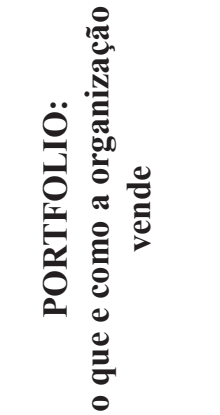 & $\begin{array}{l}\text { 18. Vender produtos "ecológicos" que } \\
\text { fazem mal às pessoas ou ao meio } \\
\text { ambiente. } \\
\text { 19. Anunciar produtos "verdes" com } \\
\text { celebridades. } \\
\text { 20. Criar eco-lojas físicas ou virtuais. }\end{array}$ & $\mathrm{X}$ & $\mathrm{X}$ & $X$ \\
\hline
\end{tabular}

Fonte: elaboração própria a partir dos autores citados.

\section{Setor financeiro: manipulação de discursos para salvar o planeta}

Desde a década de 1990 o setor financeiro tem sido pródigo no lançamento de campanhas ambientais. O Bradesco, segundo maior banco privado do Brasil, com ativos totais de mais 408 bilhões de euros ${ }^{21}$, foi um deles. Aproveitando-se do mote do "Ano Internacional do Planeta", proposto pela ONU em 2008, ele se autointitulou "o banco do planeta", e assim buscou promover-se em várias mídias diferentes. Uma destas peças, feitas para televisão e internet, é um filme de um minuto, que integra cenas impressionantes de paisagens naturais, entremeadas por imagens de crianças, tendo ao fundo trilha sonora elaborada a partir da famosa e emotiva canção Bitter Sweet Symphony, da banda britânica The Verve. A peça inclui também comovente narração do ator Wagner Moura que, então desfrutando de grande prestígio após sua participação no filme "Tropa de Elite", empresta carisma e credibilidade à propaganda, interpretando o seguinte texto:

2008 foi escolhido como o Ano do Planeta. E mais do que refletir, este tem que ser um ano para agir. Por isso o Bradesco vai focar suas ações socioambientais em uma direção: nesta direção [imagem da Terra]. E está criando o Banco do Planeta. Um banco dentro do maior banco privado do país. Nele, o cliente é um só: o planeta. E o investimento na relação das pessoas com o meio ambiente. O Banco do Planeta vai criar e apoiar ações que ajudem na questão do aquecimento global. Ele vai ampliar o papel de um banco. Porque nele o dinheiro estará a serviço do empreendimento mais importante do planeta: o modo de vida sustentável. Banco do Planeta é o Bradesco pensando completo. ${ }^{22}$

21 Todos os dados sobre os bancos apresentados nesta seção foram extraídos do estudo comparativo do jornal Valor Econômico (2016), elaborado a partir das demonstrações contábeis publicadas pelas empresas.

22 Disponível em http://www.youtube.com/watch?v=650Hs5FklkI. 
Como pode ser constatado, a propaganda incorre nas quatro categorias analíticas de greenwashing: discursividade, estética, ações e portfólio, utilizando-se de vários dos indicadores que tipicamente caracterizam cada um deles. Neste modelo, o "Banco do Planeta" é uma "eco-loja" do Bradesco, criada para vender serviços "verdes" a seus clientes, e a principal violação ética é o exagero de afirmar que "o cliente é um só: o Planeta", a partir da qual orbitam todas as demais alegações. Quanto à estética, o filme utiliza em todo seu roteiro diversas imagens ambientais, como focas, golfinhos, matas, cachoeiras, crianças, além, é claro, de diversas imagens orbitais da Terra, que também aparece no logotipo da marca ao final (Figura 3), mas não utiliza em nenhum momento imagens que aludam à operação de um banco.

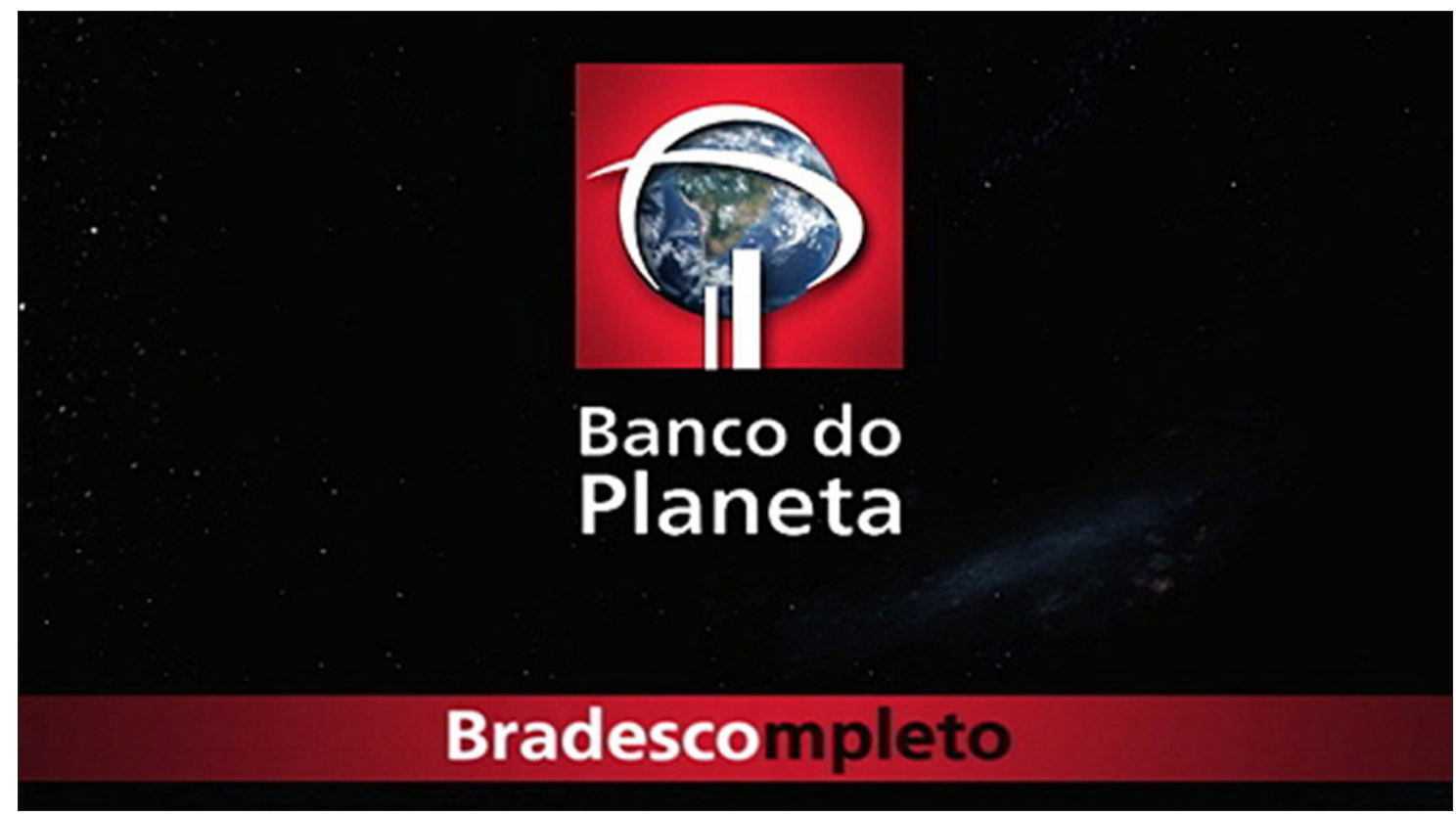

Figura 3: Propaganda "Bradesco - Banco do Planeta" Fonte: vídeo institucional

Em 2011 o banco Itaú Unibanco, maior banco privado do Brasil, com ativos totais de mais de 415 bilhões de euros, lançou uma propaganda de trinta segundos feita para televisão, onde utilizava o slogan de "o mais sustentável do mundo", que teria sido conquistado por meio de uma premiação internacional promovida pelo jornal britânico Financial Times e pela IFC - International Finance Corporation.

O Financial Times é reconhecido no mercado como um importante jornal internacional especializado em Economia, enquanto a IFC é uma instituição financeira do Banco Mundial responsável por propor e fomentar políticas de desenvolvimento econômico por meio do setor privado. O prêmio em questão na verdade chama-se "Sustainable Financial Awards", e tem a proposta de agraciar as empresas que demonstrarem capacidade de integrar aspectos sociais, ambientais e de governança corporativa a seus negócios. Ele é concedido por um júri composto por especialistas financeiros que avaliam uma série de "indicadores de sustentabilidade" definidos pela organização do prêmio e concentrados em oito categorias: abordagem estraté- 
gica, estratégias de comunicação, oportunidades, gestão de riscos, inovação, impactos, escalabilidade e papel da equipe ${ }^{23}$.

Retomando-se a propaganda em questão, em uma primeira análise, ela não parece ser um exemplo típico de greenwashing. Isto porque não utiliza no seu conteúdo imagético cenas típicas de animais, paisagens e tons esverdeados. Ao contrário, a peça busca mostrar cada frame com objetos alaranjados, que aludem à cor da identidade visual da empresa. O texto, no entanto, merece uma análise mais cuidadosa:

[Narrador] somos o banco que acaba de ser eleito como o banco mais sustentável do mundo por um dos jornais de negócios mais importantes do mundo. E pra te contar que somos o mais sustentável, reciclamos este comercial de 2006 que não falou o seu nome. É que de lá para cá muita coisa mudou. O que não muda é o nosso compromisso com você. Pode se orgulhar: o banco mais sustentável do mundo é brasileiro. É inconfundível. É feito pra você.. ${ }^{24}$

O primeiro ponto que chama a atenção é que a propaganda se refere ao prêmio de "mais sustentável do mundo", e não se utiliza do nome completo do prêmio, "Sustainable Financial Award". Ao omitir esta informação, a propaganda já comete três violações éticas: primeiro, ao manipular o discurso ambientalista, aproveitando-se da polissemia da sustentabilidade; segundo, ao fazer uma afirmação enviesada que distorce a realidade, e terceiro utilizar-se dos discursos de seus parceiros comerciais (criadores e certificadores do prêmio) para alegar sua própria sustentabilidade.

Aqui a propaganda explora a polissemia da sustentabilidade ao não deixar claro de que sustentabilidade se fala, se financeira ou ambiental, ou ambas e em que termos, já que a própria definição de "indicadores de sustentabilidade" é absolutamente controversa ${ }^{25}$. Ainda que historicamente a chamada "sustentabilidade" esteja comprometida do ponto de vista ideológico, como demonstramos anteriormente ${ }^{26}$, o fato de esta peça do Itaú omitir de propósito o adjetivo "financeira" do título original do prêmio (criando, portanto, um falso selo) compromete ainda mais o discurso ideológico da propaganda. Ele reforça a intenção do anunciante de destacar apenas o aspecto "verde" da sua premiada "sustentabilidade", já que anunciar que o banco recebeu o prêmio de maior "Sustentabilidade Financeira do Mundo" possivelmente não lhe conferiria o mesmo punch publicitário ao texto.

Um segundo ponto que chama a atenção é o uso da expressão "reciclamos este comercial". Uma vez que uma propaganda não pode ser "reciclada", a escolha intencional desta palavra neste contexto especificamente, mais que uma alternativa estilística, é uma confirmação da intencionalidade do anunciante de estabelecer uma ponte com o discurso ambientalista e "ecologicamente correto" da reciclagem. Neste momento, ela busca afastar-se, aos olhos da audiência, daquilo que um banco deveria fazer, inclusive deixando de mostrar imagens da operação de um banco ou referenciar qualquer impacto negativo dela proveniente, e aproximar-se da imagem de

23 FT/IFC, 2012.

24 Disponível em http://youtu.be/OnK816fW47g.

25 Veiga, 2010.

26 Pagotto, Carvalho e Meyer, 2017. 
protetora da natureza, infiltrando-se, do ponto de vista simbólico, na comunidade ambientalista. Ao final de seu discurso, a propaganda busca envolver as audiências com as ações do banco ao dizer que ela "pode se orgulhar" do espírito cívico e sustentável da empresa. Constata-se, assim, que propaganda incorre em três categorias e nove indicadores de greenwashing: discurso, estético e ações.

Às vésperas da Rio+20, vários bancos lançaram campanhas específicas para a ocasião. O Banco do Brasil, maior banco público do país, com ativos totais de mais de 408 bilhões de euros, lançou uma propaganda impressa de página dupla (Figura 4) em revistas de grande circulação onde, em uma delas, ensinava o leitor a fazer um cesto de papel com a técnica de origami, e na outra apresentava-se assim:

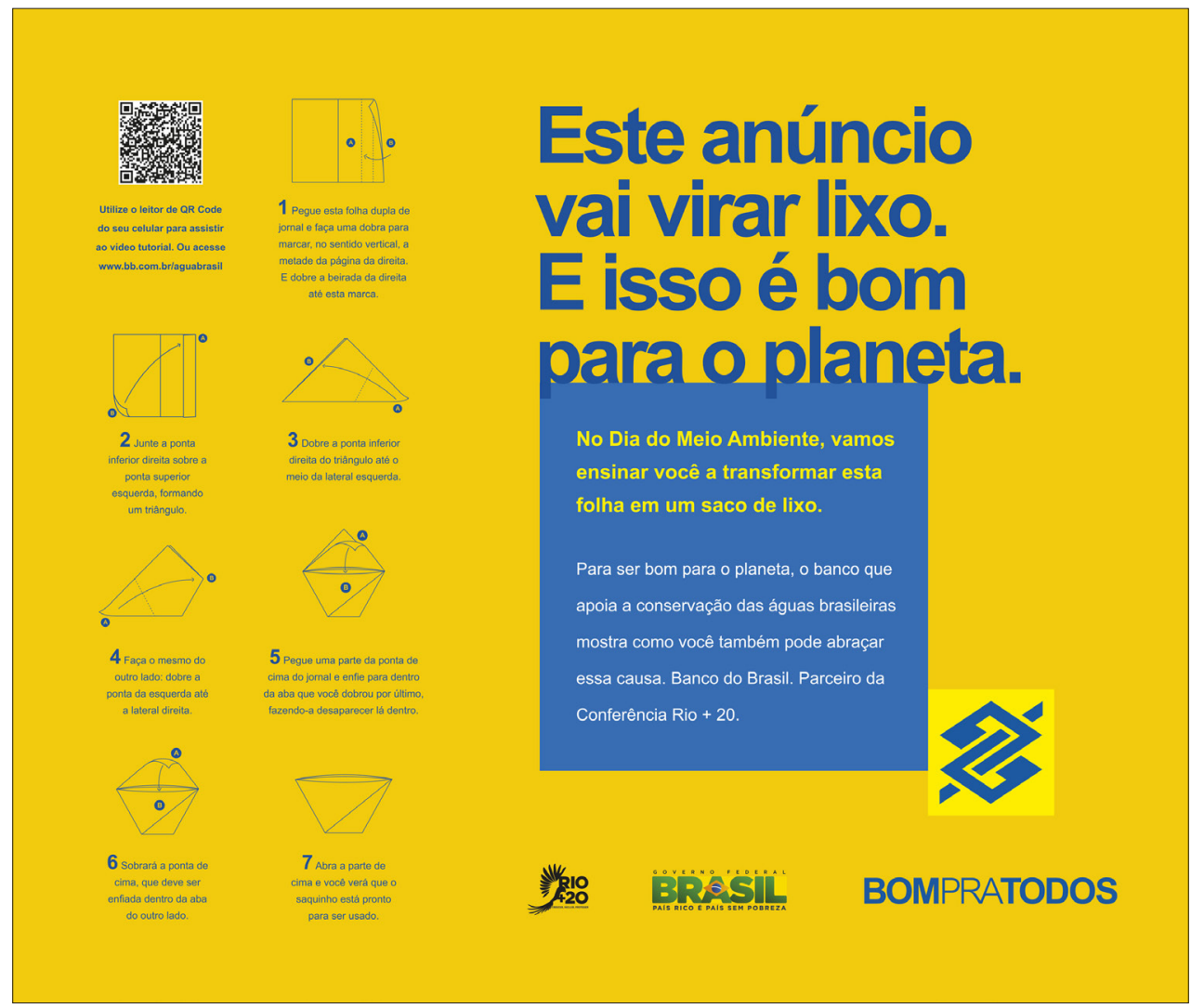

Figura 4: Propaganda "Banco do Brasil - Saquinho de lixo"

Fonte: Época, 2012.

Este anúncio vai virar lixo. E isso é bom para o planeta. No Dia do Meio Ambiente vamos ensinar você a transformar esta folha em um saco de lixo. Para ser bom para o planeta, o banco que apoia a conservação das águas brasileiras mostra como você também pode abraçar esta causa. Banco do Brasil. Parceiro da Conferência Rio+20 (Época, 2012, p 88-89).

Esta propaganda do Banco do Brasil ganhou o Prêmio Colunistas Propaganda Brasília 2012 na categoria “Peça Publicitária Relativa a Datas Institucionais” por fazer referência ao Dia do Meio Ambiente, comemorado em 5 de junho. De acordo com o quadro analítico aqui proposto, no entanto, ela incorre em nove indicadores de três categorias de greenwashing. Dizer que uma propaganda impressa virar lixo seja 
bom para o planeta, ainda que na forma de um origami, não apenas é uma manipulação discursiva ideológica, como incorreto do ponto de vista biofísico. Ensinar o cliente a fazer dobradura da própria página não tem qualquer relevância ecológica, além de retórica - mesmo porque as instruções sobre como fazê-lo estão escritas na própria página. Há associações com parceiros de negócios, como o Comitê Rio +20, além de fazer menção aos patrocínios do Banco a projetos de conservação das águas como realçadores da suposta identidade ambientalista e desvio do foco de atuação da empresa. Nesta propaganda, a redação publicitária aliada à estética minimalista do origami compõem o discurso ambientalista ao mesmo tempo em que seduzem e convidam o espectador a fazer a sua parte dizendo que "você também pode abraçar esta causa".

Já a Caixa, segundo maior banco público brasileiro, com ativos totais de mais de 365 bilhões de euros, utilizou na mesma ocasião também uma propaganda de página dupla (Figura 5). Neste caso, ela escolheu ilustrar sua publicidade com uma imagem de um barco do qual saem cata-ventos em formatos de sua logomarca enquanto navega por um plácido rio de aspecto amazônico. Na proa, em lugar de destaque, aparece o nome da embarcação: "Agência Chico Mendes"27. No rodapé da propaganda, os logotipos do Governo Federal, da Conferência Rio+20 e da própria Caixa, em referência ao seu patrocínio ao evento. O texto ao longo de uma das páginas informa:

As boas ideias são como um rio: estão sempre se renovando. Caixa - parceira da Rio+20. Não é de hoje que a Caixa contribui para a sustentabilidade e inclusão social. Prova disso são os inúmeros projetos e ações que a Caixa desenvolve em todo o Brasil. Desde o financiamento a programas de infraestrutura e habitação à implantação da agência-barco, que leva serviços bancários às populações ribeirinhas do Amazonas. Agora, a Caixa se une a formadores de opinião de todo o mundo na Rio+20. Uma oportunidade para aprender, divulgar novas ideias e reafirmar o compromisso da Caixa com você e com o planeta. (Época, 2012, p 2-3)

A análise desta propaganda a partir dos referenciais aqui propostos mostra que ela incorre em oito indicadores das quatro categorias de greenwashing. Quanto ao discurso, dizer que a empresa reafirma seus compromissos com o planeta é claramente exagerado. No que se refere à estética, o uso de imagens ambientais manipuladas e idealizadas na propaganda dá o seu tom ecopornográfico em sentido estrito ${ }^{28}$, que ganha não apenas força na associação aos nomes da Rio +20 e de Chico Mendes, mas também caracteriza sua infiltração na comunidade ambientalista. Já quanto às ações e portfolio, a propaganda procura desviar o foco de ação para projetos paralelos, como o da própria agência-barco, que funciona como uma espécie de "eco-loja" de serviços bancários, além de tratar seus investimentos em infraestrutura e habitação, que são suas obrigações legais enquanto banco público, como "contribuição para sustentabilidade", destacando apenas aspectos positivos de sua atuação.

27 Famoso ativista brasileiro, sindicalista, ambientalista e representante de comunidades tradicionais da Amazônia, morto em 1988 por fazendeiros contrários à sua atuação.

28 Conlogue, 2013. 


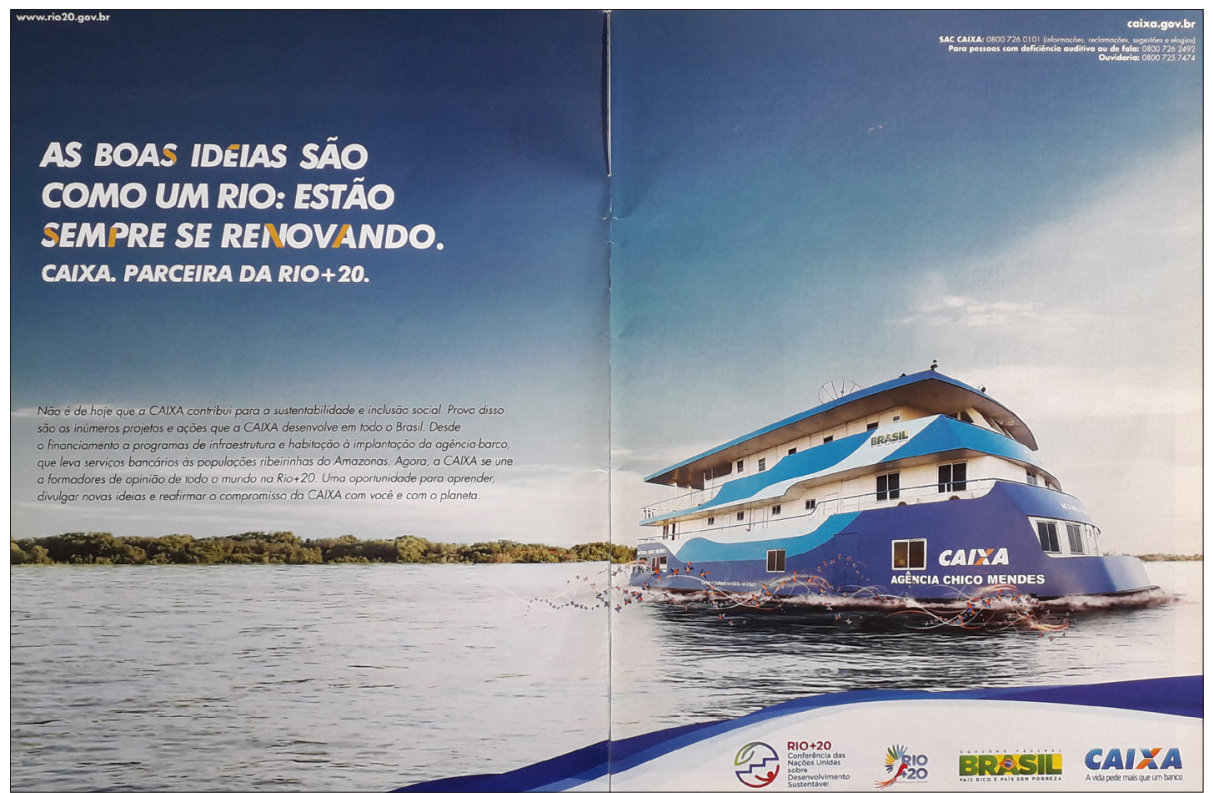

Figura 5: Propaganda "Agência-barco", da Caixa fonte: Época, 2012

Outro que aproveitou a oportunidade da realização da Rio+20 para promover sua "sustentabilidade" foi o Santander, terceiro maior banco privado do Brasil, com mais de 204 bilhões de euros em ativos totais. Em propaganda de página dupla feita para mídia impressa especialmente para esta ocasião, o banco fazia referência ao "tripé da sustentabilidade":

O Santander assumiu o compromisso de fazer negócios e gerar ideias para uma sociedade mais sustentável. Por isso, participa da Rio+20. O Santander participa da Rio+20 porque assumiu um compromisso com a sustentabilidade. E um banco sustentável cresce mais em uma sociedade e economia que seguem os mesmos princípios. Por isso, patrocinamos fóruns para a discussão de novas ideias e apoiamos projetos como o do ônibus movido a hidrogênio, que poderá contribuir para uma mobilidade urbana mais sustentável no futuro. Para que, cada vez mais, possamos fazer negócios que tragam bons resultados para todos: banco, sociedade e planeta. (Época, 2012, p. 68-69)

O que Santander, Banco do Brasil, Caixa, Bradesco e Itaú têm em comum, no entanto, não é apenas seu "compromisso com a sustentabilidade" ou "com o planeta". A soma dos ativos destas cinco empresas, tomados a partir de seus balanços contábeis publicados em 2016, chega à casa de 1.800 bilhões de euros. Para efeito ilustrativo, vale mencionar que o valor de todo o produto interno bruto (PIB) do país naquele ano foi de 1.376 bilhões de euros.

À luz da teoria da propaganda de Herman e Chomsky ${ }^{29}$, seria possível dizer que propagandas de instituições tão poderosas que ensinam o leitor a "ser bom para o planeta" e fazer origamis estão, na verdade, utilizando-se da estratégia de dirigir-se ao público como criaturas de pouca idade com o objetivo de mantê-lo na ignorância

29 Herman e Chomsky, 2003. 
e na mediocridade para torná-lo incapaz de compreender as tecnologias e métodos de controle social.

A partir do modelo analítico resumido no Quadro 2 e da análise de propagandas dos cinco maiores bancos brasileiros, pode-se construir um quadro comparativo de como as empresas deste setor operam o greenwashing (Quadro 3). A estratégia geral consiste em ( 1 ) infiltrar-se na comunidade ambientalista e manipular seu discurso, destacando apenas aspectos positivos de sua atuação e (2) ocultar os resultados de sua operação por trás de campanhas midiáticas sedutoras, ações em conjunto com parceiros e desvio do foco da atenção das audiências para projetos paralelos.

Quadro 3: Comparação dos indicadores de greenwashing nas peças publicitárias selecionadas do setor financeiro.

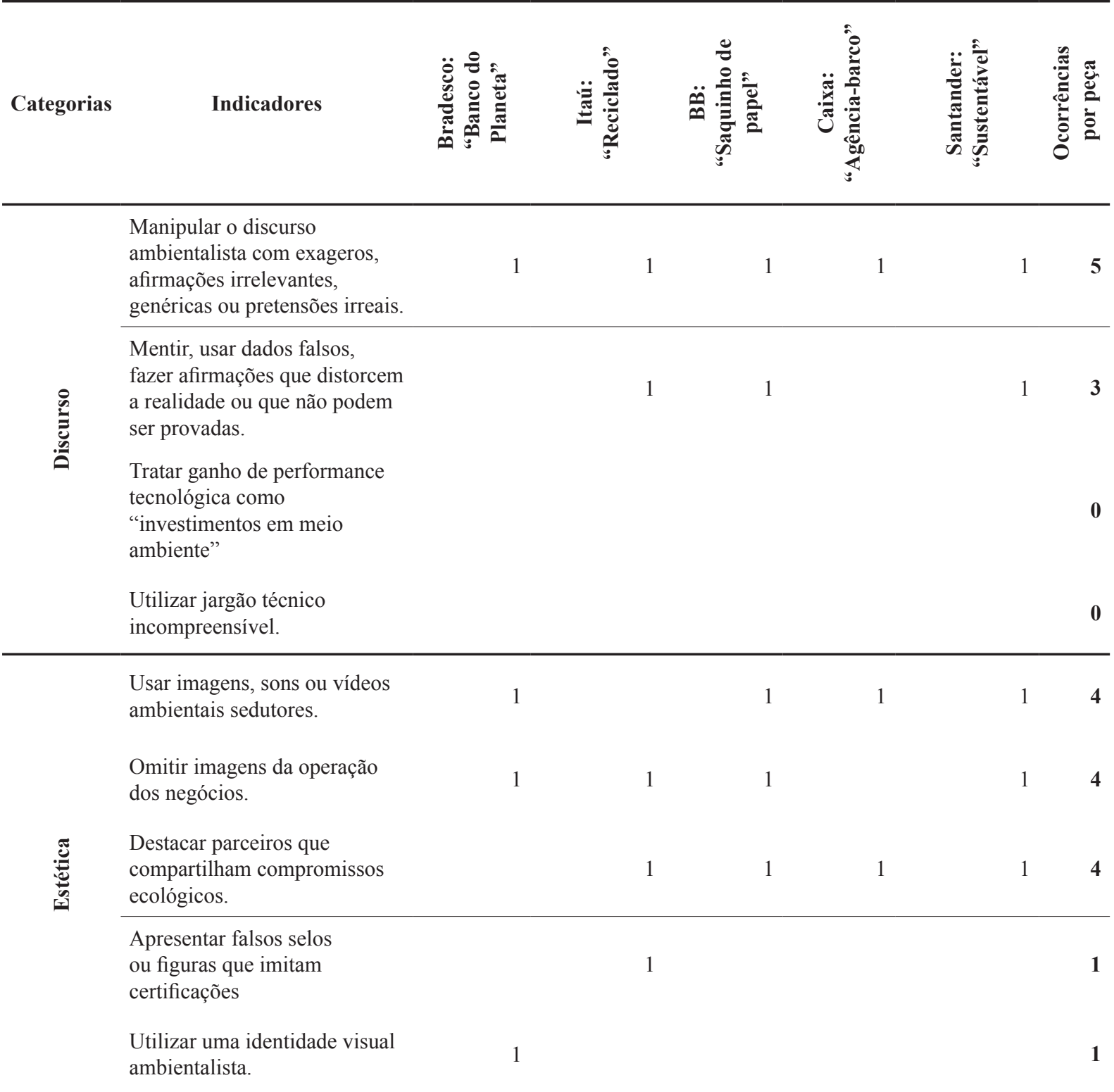




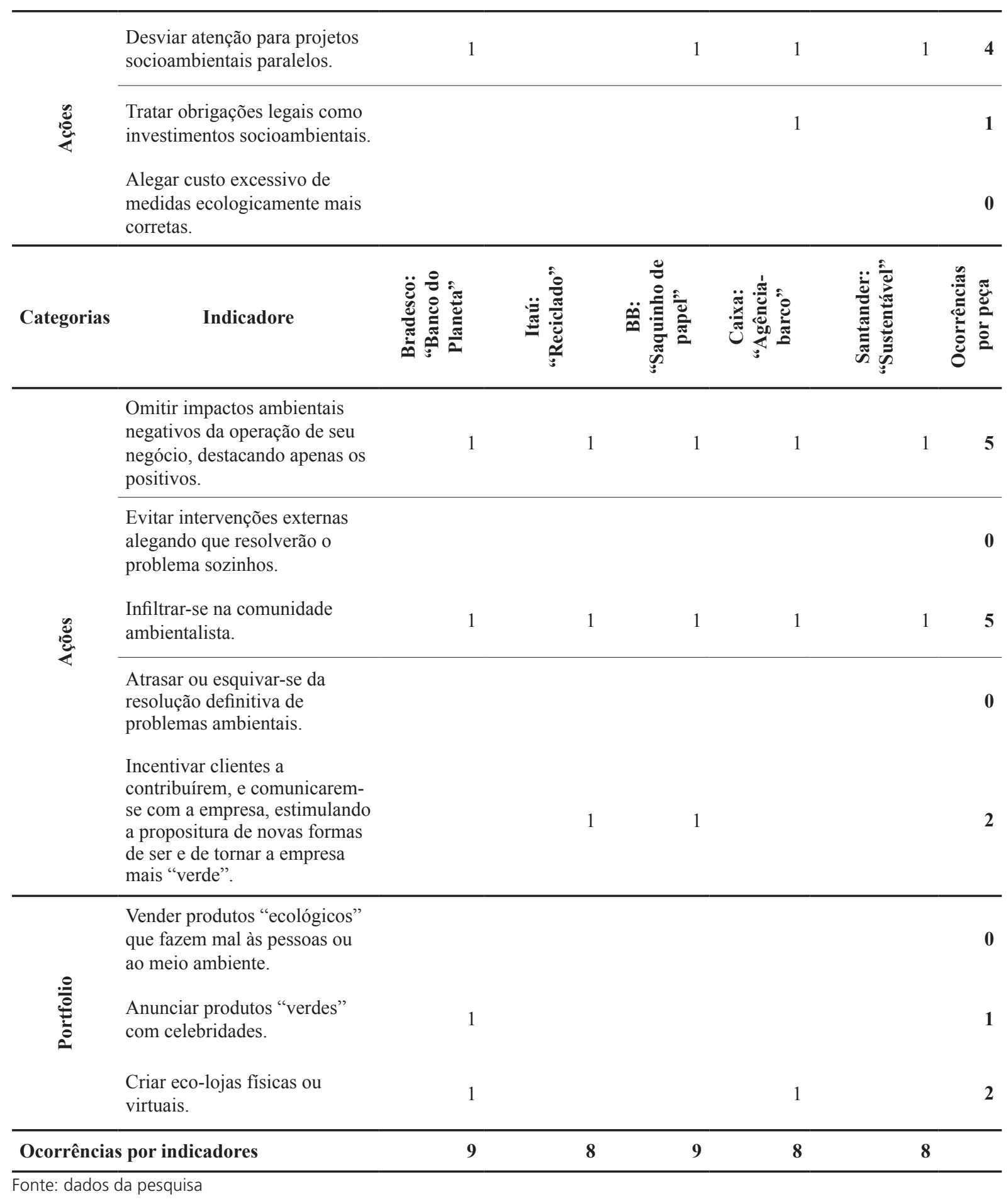

\section{Setor automobilístico: eficiência, liberdade e alienação}

Outro pródigo setor no lançamento de propagandas ambientais para promoção de seus produtos foi o automotivo. Foram analisadas peças publicitárias de algumas das principais montadoras do Brasil: Ford, Fiat, Volkswagen, General Motors e Jeep.

O Ecosport é um veículo da Ford lançado em 2003 no Brasil e em 2014 na Europa. Apostando em um novo segmento, que posteriormente ficaria conhecido como "aventureiro-urbano" ou "SUV compacto", o produto foi um grande sucesso de ven- 
das devido às suas características estéticas, preço reduzido em comparação com outros similares disponíveis à época e pela força de suas campanhas promocionais - com forte apelo publicitário ao meio ambiente como alternativa ao estilo de vida urbano. Como seu próprio nome parece sugerir, uma junção de ecologia e esportes radicais em meio à poluição e ao tráfego cada vez pior das grandes cidades. Até 2017 foram mais de 150 mil unidades vendidas na Europa, e mais de um milhão no Bra$\operatorname{sil}^{30}$.

Em propaganda de televisão de 2008 o anunciante informava de forma quase poética:

No meu mundo, praça é ilha. Luminoso é vagalume. Fumaça é algodão. E todo cheiro é perfume. A lombada é jacaré. Pedra sabe andar. Telhado é passarinho E a menina foi casar. Muito prazer, eu sou o novo Ford Ecosport. ${ }^{31}$

A propaganda mistura filmagens a efeitos especiais que mostravam o carro circulando numa cidade de ruas praticamente desertas e onde animações revelavam animais e cachoeiras pela rua, flores saindo de caminhões de lixo e céu com nuvens de algodão.

Em outra peça, de 2012, propaganda televisiva do veículo conta a história de "Clara, a consciente". A atriz percorre estradas de terra com seu carro jogando sementes por onde passa, até chegar num típico mercadinho rural, onde compra dezenas de passarinhos engaiolados, e os leva para serem soltos, ao que é aplaudida por moradores locais. O texto da propaganda diz:

[Letreiro com fontes em forma de folhas] Além das fronteiras. Ecológica. Apresentando: a consciente, a natureza, o novo Ecosport.

[Locutor com voz de narrador desportivo] Viajar por aí sentindo o cheiro do mato e espalhando sementes pelas estradas. Esta é uma das coisas que a Clara mais gosta de fazer. Pelas suas contas, já foram mais de cinco mil árvores plantadas. Para ela, homem e natureza tem que viver sempre juntos. E livres.

[Clara "real", que aparece num pequeno frame à direita] Ter liberdade dentro de um Ecosport é dar liberdade à natureza. Isso pra mim é ir mais longe. ${ }^{32}$

As duas mencionadas propagandas do Ecosport contêm nitidamente vários traços característicos de greenwashing. Eles vão da apropriação das imagens e do discurso que fala sobre liberdade e contato com a natureza (Figura 6), numa alusão propositadamente bastante dissociada da realidade da maioria dos motoristas urbanos. O que a propaganda anuncia não é apenas o carro, mas o estilo de vida enquanto objeto de desejo.

Em ambas as propagandas, as peças procuraram utilizar uma linguagem narrativa e visual que remetem propositadamente a um mundo infantilizado. De acordo com a Teoria da Propaganda de Herman e Chomsky ${ }^{33}$, esta é uma forma de provocar

30 De acordo com dados disponíveis em www.ford.com e www.ford.com.br

31 Disponível em https://www.youtube.com/watch?v=sHQQ-HWZOqk.

32 Disponível em https://www.youtube.com/watch? $v=\mathrm{m} 05 \mathrm{cB} 9$ _Nq5E.

33 Herman e Chomsky, 2003. 


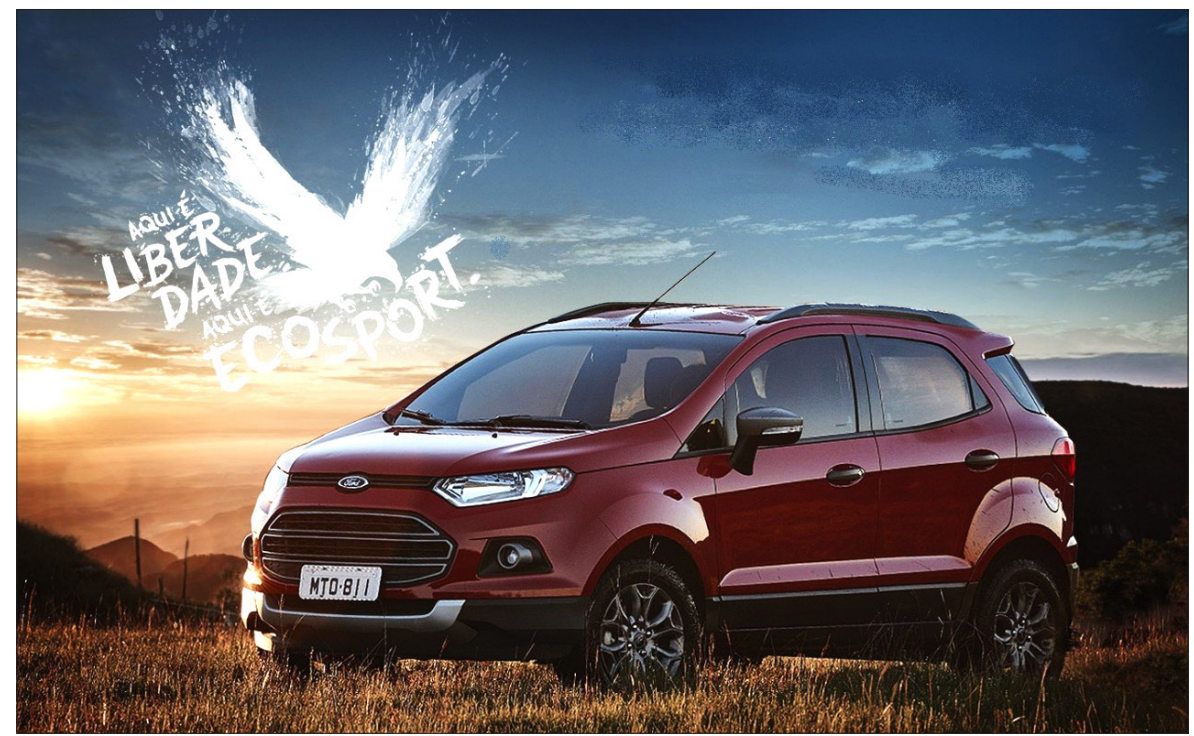

Figura 6: Propaganda do Ford Ecosport Fonte: www.ford.com.br.

respostas ou reações mais infantis e desprovidas de senso crítico.

No caso da segunda propaganda, o fechamento da peça com o depoimento da Clara (supostamente) "verdadeira" confere um tom de autenticidade à propaganda. A própria Clara, uma mulher com cerca de quarenta anos, de aparência despojada e algum sobrepeso, estabelece uma relação identitária entre público-alvo e anunciante. Do ponto de vista psicológico, cria uma ressonância, isto é, uma identificação com a audiência e com isso permite que ela possa se identificar com o produto e o estilo de vida ofertados - ainda que sua fala não traduza sentido prático algum.

Explorando o novo mote trazido pelo Ecosport, montadoras empenharam-se em adaptar seus modelos convencionais para modelos "fora de estrada". Ainda que do ponto de vista automecânico estes produtos tenham muito pouco ou nada que pudesse lhes assegurar algum desempenho superior em estradas não asfaltadas, da perspectiva estética a proposta teve sucesso no mercado. Para auxiliar a vender a ideia do fora de estrada, propagandas mostram motoristas dirigindo em estradas vazias por paisagens deslumbrantes, via de regra sozinhos ou no máximo acompanhados de belos cônjuges, enquanto acionam parafernálias multimídias e sorriem. Idealização de consumo para os motoristas do mundo real, cada dia mais estressados com congestionamento, falta de espaço, poluição, barulho, taxas e perda de tempo proporcionados pelo trânsito das grandes cidades. A proposta das propagandas automotivas é vender para este público não apenas um meio de locomoção, mas liberdade e distanciamento da realidade.

Um dos produtos da Fiat, por exemplo, foi o seu "Idea Adventure", baseado no conceito europeu do "Idea 5terre", e que trouxe o slogan "a vida na cidade é uma aventura". Uma das propagandas deste carro, um filme de trinta segundos lançado em 2010 e chamado "Ilusões" ${ }^{34}$, mostra um motorista que, ao dirigir o veículo, vê animais e paisagens selvagens pela cidade, até confundir uma atleta em trajes su-

34 Disponível em http://www.youtube.com/watch?v=MS7IiJf21xo. 
mários com uma propaganda de outdoor. Já o modelo "Fiat 500" utilizou-se de uma propaganda com mais efeitos especiais em um cenário futurista. O filme de um minuto $^{35}$, lançado em 2009, mostra o veículo que após ser abastecido com uma única gota de combustível circula rapidamente entre outros carros que parecem monstros desajeitados, enquanto é observado por margaridas mecânicas e turbinas de energia eólica. O locutor narra um texto em que afirma que "este é um novo tempo. Um tempo em que todos podemos nos sentir mais livres, respirar melhor. Um tempo em que dividimos não apenas sonhos, mas também o planeta em que vivemos". Já em 2017 a Fiat foi acusada de greenwashing pela Proteste ${ }^{36}$, uma associação de defesa do consumidor, por anunciar um novo modelo de pneus, chamados de "superverdes", supostamente mais resistentes, cuja publicidade foi descontinuada pela montadora.

A Jeep chegou ao Brasil em 2015 e seu principal foco quanto à comunicação mercadológica foi o apelo fortemente emocional ao conceito de "fora de estrada" e à natureza. Uma de suas propagandas traz jovens praticando esportes radicais em matas, penhascos e praias e o seguinte discurso:

A gente não chegou pra fazer o $4 \times 4$ mais eficiente da categoria. A gente chegou pra fazer [letreiro: AVENTURAS]. Nem pra criar o mais moderno câmbio automático de 9 marchas. Chegou pra criar [ATALHOS]. Não estamos aqui só pra fazer o carro mais seguro fabricado no país. Estamos aqui pra fazer [VIAGENS]. Também não viemos criar o único SUV compacto com motor flex ou diesel. Viemos criar [LIBERDADE]. Nem pra produzir a tecnologia Uconnect. Nós viemos pra produzir [ENCONTROS]. É, a gente não chegou pra criar duas opções de teto solar. A gente chegou pra criar [SONHOS]. Chegou Jeep Renegade. Fabricado no Brasil pra VOCÊ fazer história ${ }^{37}$.

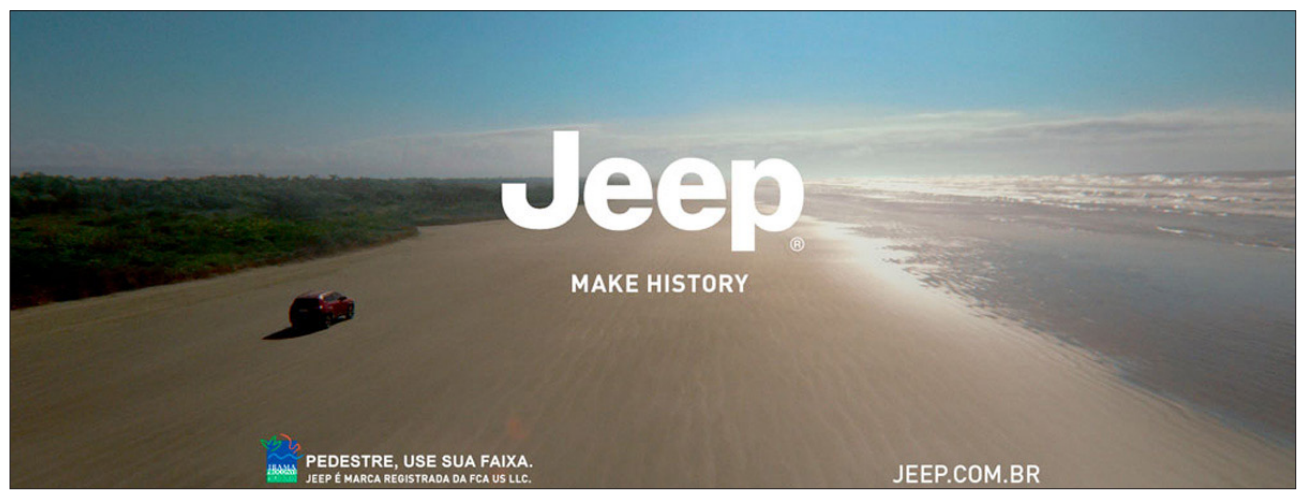

Figura 7: Propaganda institucional da Jeep do Brasil

Fonte: www.jeep.com.br

A análise desta propaganda mostrou que ela incorre em dez indicadores das quatro categorias de greenwashing. O discurso foi o elemento mais proeminente, pois traz manipulações, pretensões irreais, afirmações que não podem ser provadas e associa performance tecnológica a vantagens ambientais inexistentes, como por exemplo, entre o número de marchas e os "atalhos", ou entre o uso de diesel e a "liberdade". Quanto à estética da propaganda, explora fortemente a identidade, os sons

35 Disponível em http://www.youtube.com/watch?feature=player_embedded\&v=HfezAZhiLDQ.

36 Informações disponíveis em https://www.proteste.org.br/

37 Disponível em https://www.youtube.com/watch?v=DkLgJp7CBnQ. 
e imagens ambientais (Figura 7), ao mesmo tempo e que omite imagens relacionadas à operação dos negócios. Já quanto às ações e portfolio, a propaganda desconsidera os impactos negativos do negócio e do produto e ainda explora fortemente o pertencimento a uma comunidade ambientalista "aventureira".

No caso da Volkswagen, duas propagandas são dignas de menção aqui. A primeira é um filme de um minuto e meio feito para televisão e internet em 2005. Nele, um rapaz lava seu carro no jardim com uma mangueira, quando percebe que seu relógio de pulso foi danificado pela água, e então tem o seguinte devaneio:

Droga de relógio. Ah, como seria bom se tudo fosse bem feito que nem (sic) um Volkswagen. As coisas iam ser menos frágeis, menos desgastáveis. Tudo ia durar muito mais. E, por exemplo, se eu quisesse, poderia ter só um fogão, só um celular, só um aparelho de som [sucedem-se imagens de objetos que se reparam sozinhos].

E as coisas iam ser feitas não só pra seguir a última moda, ou pra parecer que são modernas. Mas iam ter que ser bonitas por muito tempo. Como as coisas iam durar mais, as pessoas não iam precisar comprar tanto, e iam gastar muito menos. As lojas iam vender menos, e aí nunca ia ter fila [imagens de lojas vazias].

As empresas não iam precisar anunciar tanto, ia ter menos comercial na televisão, menos anúncios nas revistas, menos propaganda invadindo a rua [desaparecem placas e cartazes colados em um prédio histórico].

As fábricas iam produzir menos, e aí iam usar menos matéria-prima, e iam precisar de menos gente... [fumaças voltam para dentro de chaminés, explosões de mineradoras são revertidas e um personagem de desenho animado é chutado para fora de uma empresa].

Peraí! Mas e eu? Aí eu ia acabar ficando sem trabalho. Aí eu não ia poder comprar meu Volkswagen! [desaparece o carro que o jovem está lavando. Neste momento, todo o filme é passado ao contrário em velocidade acelerada].

Pensando bem... que bom que nem tudo é tão bem feito quanto um Volkswagen! [jovem respira aliviado $]^{38}$.

Os conflitos éticos desta propaganda são tão flagrantes (além de ecopornográficos), que motivaram a Justiça Estadual de Minas Gerais, por meio de ação civil do Ministério Público, a suspender liminarmente sua veiculação em todo o Estado e pedir uma indenização por dano moral coletivo no valor de R\$ 10 milhões ${ }^{39}$. Após esta decisão, a empresa evitou comentar o assunto, e decidiu interromper a veiculação da propaganda em todo o Brasil, informando apenas por meio da imprensa que antes de ir ao ar, ela foi testada com consumidores, que não teriam indicado "nenhuma conotação negativa"40.

A segunda campanha da Volkswagen que merece ser mencionada aqui foi a "Casa Ecológica", criada na ocasião do lançamento do veículo "Polo Bluemotion", em 2009. O filme ${ }^{41}$ mostra um jovem que apresenta a seu amigo todos os equipamentos "ecológicos" instalados em sua casa, incluindo painéis solares, caixa d'água para retenção de água pluvial, lixeiras de coleta seletiva, caixa de compostagem para adubar uma mini-horta, entre outros. Enquanto vai apresentando todas as traquitanas, ele

38 Disponível em http://www.youtube.com/watch?v=6ORHynh9mjw.

39 Peixoto, 2005

40 Folha, 2005.

41 Disponível em http://www.youtube.com/watch?v=Pc4OGCnP5zE. 


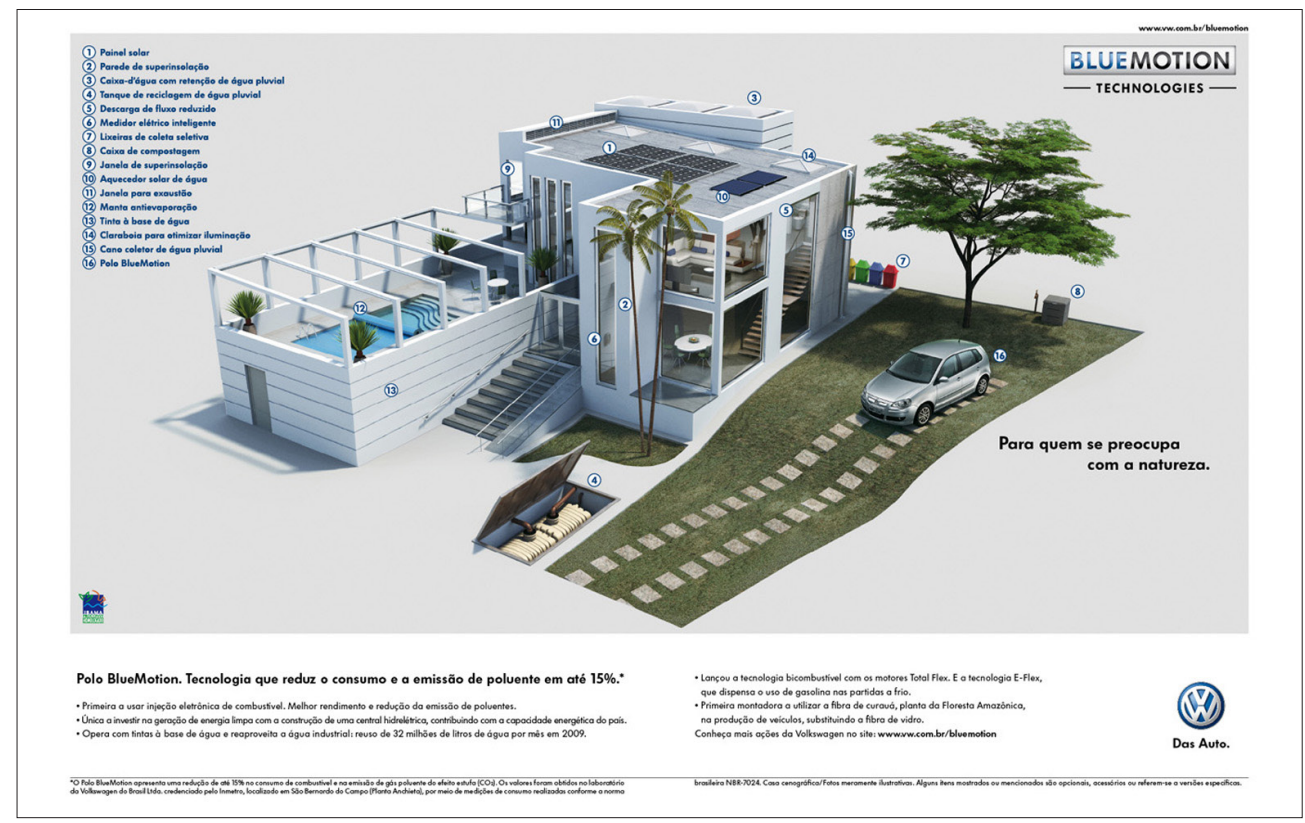

Figura 8: Propaganda impressa do VW Polo Bluemotion Fonte: www.vw.com.br

menciona em determinado momento "e este é meu carro", e segue apresentando os itens da casa, dando a entender que o veículo seria também ecologicamente correto. Entra então um narrador informando: "Polo Bluemotion: até 15\% menos de CO2. Parece pouco. Mas faz muita diferença".

A versão impressa desta propaganda (Figura 8) consiste em um anúncio de página dupla que mostra a planta da tal casa com todos seus itens "ecológicos", inclusive o veículo, e traz no canto inferior direito em destaque o slogan: "Para quem se preocupa com a natureza". No rodapé do anúncio, outras explicações informam que "Bluemotion", cujo logotipo aparece em outro canto da página, é a tecnologia da Volkswagen que reduz 15\% de emissões, e que de acordo com a própria empre$\mathrm{sa}^{42}$, seria rebatizada para "Ecomotion" em 2010. O anúncio informa também outras ações ditas "ecológicas", como "única a investir na geração de energia limpa com a construção de uma central hidrelétrica, contribuindo para a capacidade energética do país", "lançou a tecnologia bicombustível com os motores Total Flex" e "primeira montadora a utilizar a fibra de curauá, planta da Floresta Amazônica, substituindo a fibra de vidro", entre outras afirmações correlatas a projetos paralelos da empresa.

A General Motors também se aproveitou do prefixo "eco" para batizar um sistema de equipamentos de seus veículos. No entanto, após denúncia da Proteste junto ao Conselho Nacional de Autorregulação Publicitária - CONAR, a empresa rebatizou o sistema para "Econo System" e mudou sua propaganda, alegando que o "eco" não era de "ecológico", mas de "econômico".

Outras propagandas que adotam formas mais sutis de greenwashing, no entanto, não tem recebido a mesma atenção de associações ou do Conselho. Uma delas foi a de lançamento do luxuoso SUV da marca, chamado Equinox, em 2017. Feito para

42 Disponível em http://www.vwbr.com.br/BlogdaVolkswagen/category/Eventos.aspx. 
internet, o filme de um minuto e meio, mostra um alto executivo de meia-idade que encerra seu expediente, busca sua família e partem para um dia em sua casa de cam$\mathrm{po}^{43}$. Embalada por uma trilha sonora épica, não há falas, apenas letreiros, onde as

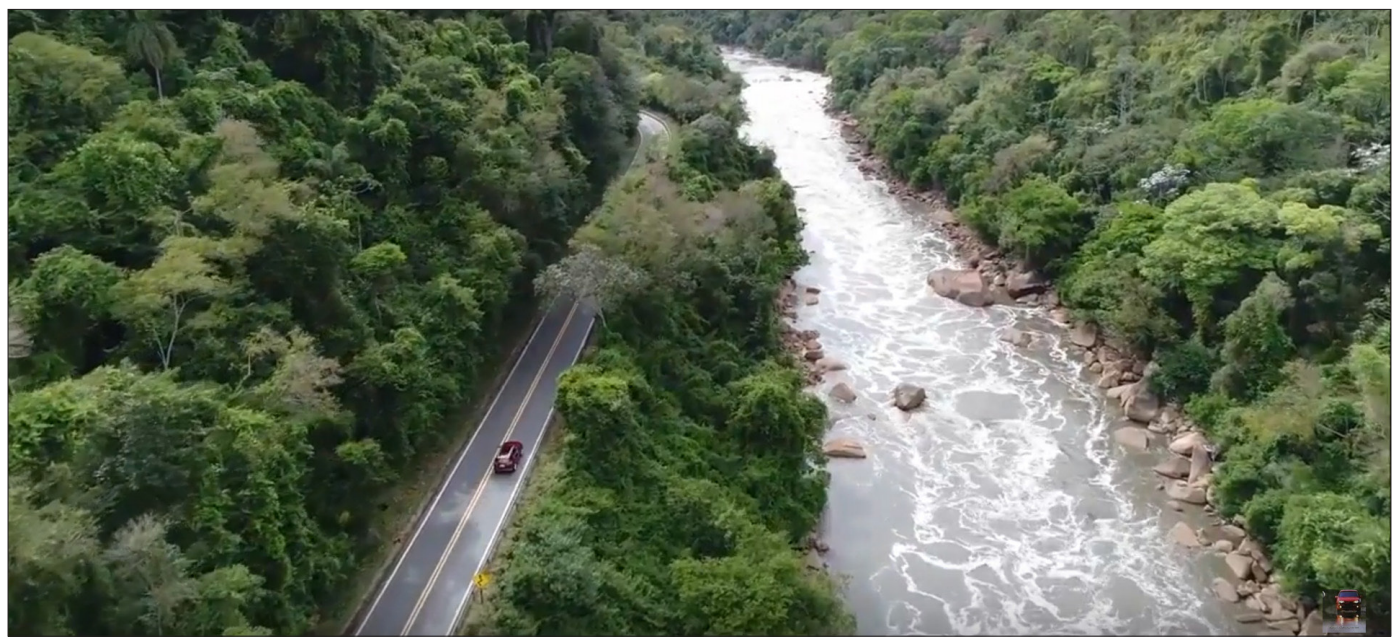

Figura 9: Frame da propaganda "GM - Equinox"

Fonte: vídeo institucional

seguintes palavras acompanham o enredo: “Liderança. Admiração. Prestígio. Adrenalina. Conquista. Poder".

Nesta propaganda, há muitas mensagens subliminares e estereótipos: desde as cenas de abertura mostrando o imponente prédio da empresa, a mansão onde sua jovem e caucasiana família reside, com esposa, dois filhos e um golden retrivier, passando pelas imagens de estradas, florestas, rios e cachoeiras que são rasgadas velozmente pela potência do carro (Figura 9) até chegarem ao clímax do campo, com lago e jet ski - que assim como os demais elementos, apenas o homem domina. Uma síntese do padrão ecopornográfico patriarcal.

Este tipo de abordagem da questão de gênero é recorrente na publicidade da GM, e visa estabelecer ressonância entre seus principais produtos, que incluem caminhonetes, pick-ups, SUVS e esportivos, com os respectivos públicos-alvo. No entanto, em 2018, com o avanço da onda conservadora brasileira e em pleno ano eleitoral, uma propaganda para televisão da caminhonete S-10 destacou-se. Ela mostrava um fazendeiro que acorda pela manhã, lê em seu celular a manchete "Agronegócio e desmatamento", e então sai em sua caminhonete para visitar sua fazenda. Ao fundo, um narrador fala em tom desafiador:

Algumas pessoas vão sempre apontar o dedo pra gente que vive no campo. Mas nós vamos nos levantar ainda mais cedo pra cuidar do rebanho, do futuro da fazenda e até do futuro de quem aponta o dedo. Porque sabemos que se pararmos este país também para. É hora de valorizar quem carrega o país nas costas. Nova Chevrolet S-10 2018. Find new roads. ${ }^{44}$

O destaque aqui se dá não pela ocorrência de greenwashing ou de discurso machista, mas pelo alinhamento político-ideológico antiambientalista. Trata-se de ou-

43 Disponível em https://www.youtube.com/watch?v=cupy5-s5-9Y.

44 Disponível em: https://www.youtube.com/watch?v=io3q7BSRt3A. 
tra categoria de cinismo que começa a frequentar os espaços publicitários e que dá voz ao tipo de sociedade que Boaventura de Souza Santos bem descreveu como sendo "politicamente democrática, mas socialmente fascista"45.

Com relação às propagandas citadas anteriormente, pouco importa se as ações estão alinhadas à estratégia econômica de redução de custos com a obtenção de matérias-primas alternativas e energia mais barata: seu discurso visa promover a empresa por seu bom-mocismo em relação ao maio ambiente. A utilização de expressões como "blue", "eco", "liberdade", "aventura" e "natureza” segue a estratégia criticada por Layrargues ${ }^{46}$, de apropriar-se do discurso ecológico, e então subvertê-lo em relação às suas intenções originais. Assim, totalmente alinhada ao discurso da economia ambiental ${ }^{47}$, a propaganda não apenas cumpre a função de anunciar o produto, como capitaliza para a organização os louros de apresentar-se como uma empresa engajada. De acordo com a pesquisadora Denise Azevedo dos Santos ${ }^{48}$, que também estudou as propagandas da Volkswagen, "fica evidente, mais uma vez, um discurso centrado na ação individual como motor da promoção de um ambientalismo comercial: são as pequenas ações gerando os grandes negócios".

Já o episódio que ficou conhecido como "o escândalo da VW" aconteceu em 2015 após a companhia admitir que tinha instalado em algumas linhas de veículos um mecanismo desenvolvido especificamente para fraudar o sistema de monitoramento de emissões realizado pelas agências ambientais do governo. Para alguns autores, este episódio inaugura um novo tipo de greenwashing: o da manipulação enganosa ${ }^{49}$.

Propagandas e ações como estas de fato prestam um grande desserviço à sociedade tanto por contribuir para a deseducação de suas audiências ao promover uma distorção da realidade, como também por reforçar valores egoístas da satisfação de necessidades individuais por meio do consumo de bens e à custa do sacrifício coletivo.

Para fechar esta seção do artigo, o quadro 4 traz um panorama comparativo dos indicadores de greenwashing nas propagandas amostradas do setor automotivo. Elas sugerem que a estratégia geral adotada pelas montadoras é de ( 1 ) explorar a suposta mobilidade proporcionada pelo veículo como meio de acesso à natureza, idealizando o motorista, seus amigos e familiares como ambientalistas, ao mesmo tempo em que ignora toda uma gama de impactos socioambientais relacionados à fabricação, posse e utilização de um veículo; e (2) tratar os ganhos de performance tecnológica como investimentos em meio ambiente, ainda que o saldo de seus supostos benefícios à sociedade e à natureza não estejam demonstrados.

45 Souza Santos, 2016.

46 Layrargues, 1998.

47 Cavalcanti, 2010.

48 Santos, 2011.

49 Siano et al., 2017. 
Quadro 4: Comparação dos indicadores de greenwashing nas peças publicitárias selecionadas do setor automotivo.

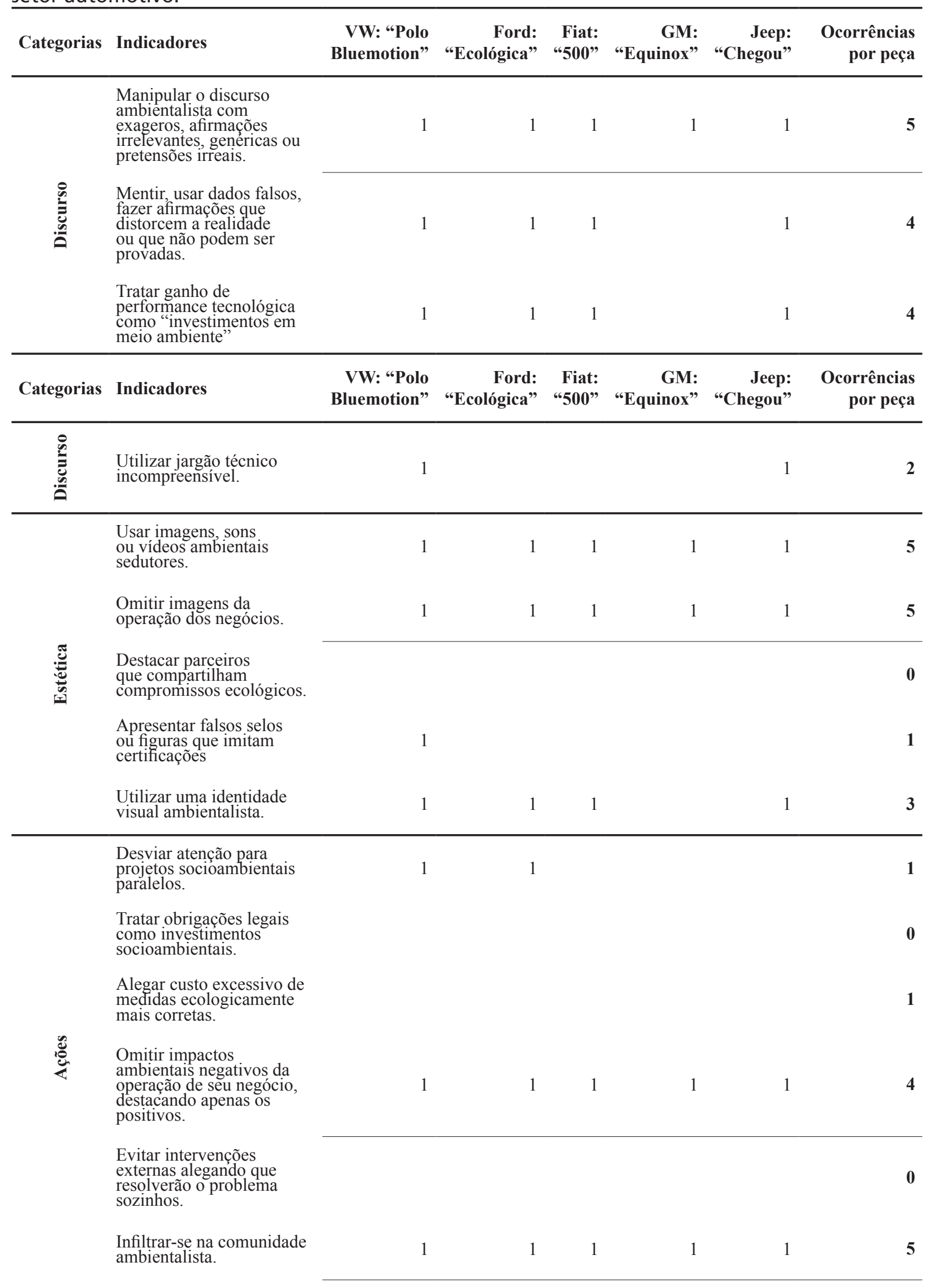




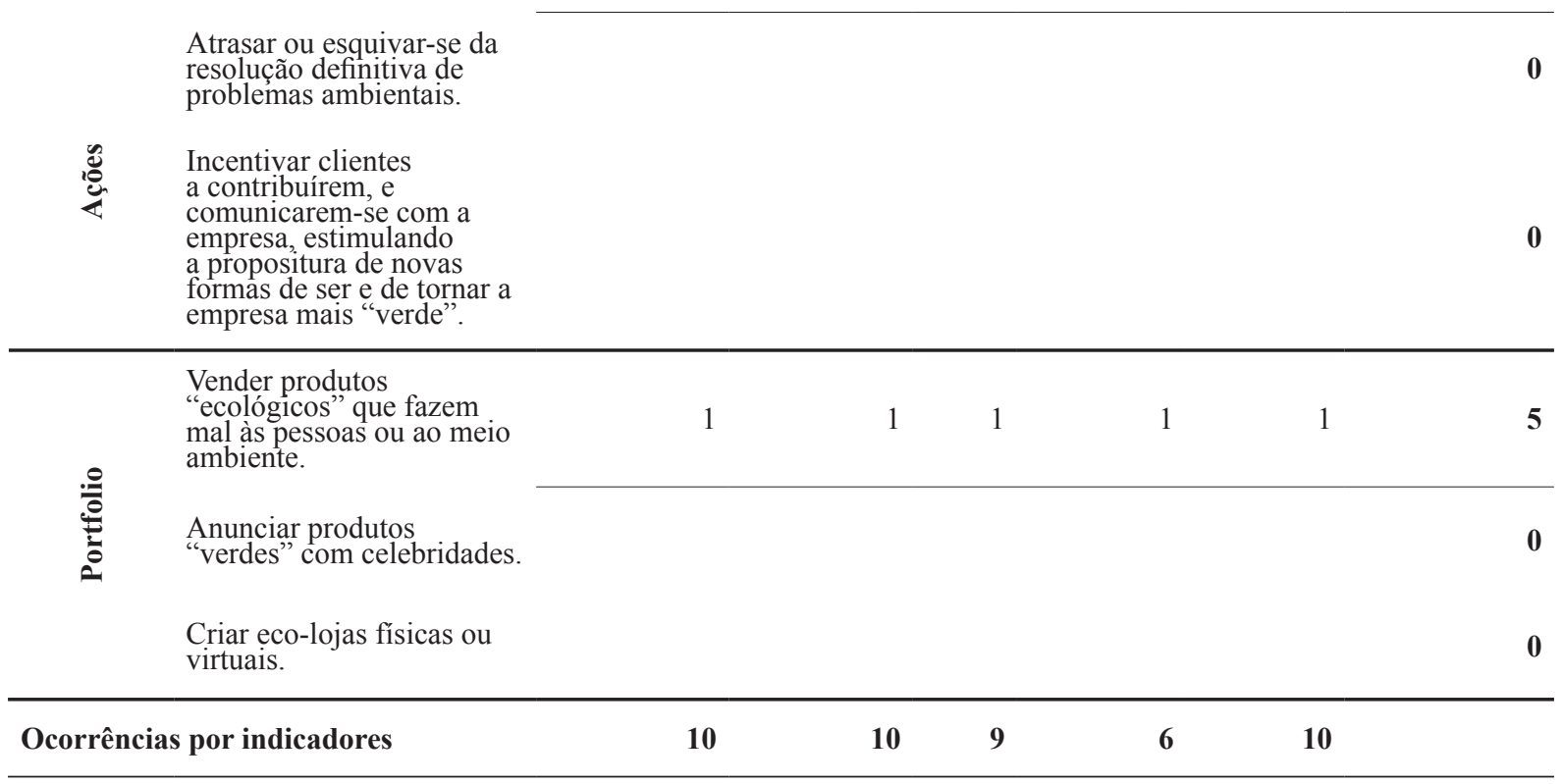

Fonte: dados da pesquisa

\section{O que revelam as propagandas}

Após a análise das dez propagandas apresentadas neste artigo é possível discutir alguns pontos que se destacam por sua recorrência. Primeiro, nenhuma das propagandas faz qualquer referência à crise socioambiental sistêmica, ainda que seus produtos, serviços ou sua própria imagem institucional se proponham a trazer algum tipo de "solução", melhoria ou atendimento às necessidades humanas. No caso das montadoras, prevalece a valorização hedônica do indivíduo sobre a coletividade, enquanto no setor financeiro o enfoque é sobre o "planeta" de forma indistinta. Segundo, os indicadores de greenwashing mais prevalentes são aqueles relacionados à manipulação do discurso ambientalista e a inserção das organizações como parte da comunidade ambientalista.

Pode-se observar também como o grenwashing na prática não se apresenta de maneira uniforme, mas em variados "tons de verde", a depender do setor econômico e das peças publicitárias. Da mesma forma, a ecopornografia, enquanto violação estética e ideológica de elementos da natureza, aparece como mais uma dimensão realçadora do greenwashing, nem sempre presente, mas que lhe adiciona um ingrediente alienador a mais ao reafirmar valores de uma moralidade patriarcal hegemônica.

No debate a respeito das mensagens que as propagandas chamadas ambientais trazem, uma questão poderia ser colocada: além dos oportunismos identificados nos vários exemplos citados, e que são apenas uma pequena mostra do que ainda poderíamos colher, seriam elas apenas mais um modismo publicitário, ou será que refletem algum nível de conscientização e de sinalização por mudanças - ainda que motivadas apenas pelos riscos que a crise ambiental representa à integridade dos 
negócios?

A empresa de consultoria PwC - PricewaterhouseCoopers publicou um relatório chamando a atenção para a necessidade de adaptação dos negócios perante o aquecimento global:

Os líderes empresariais têm pedido maior clareza em relação às metas para as mudanças climáticas. Hoje uma coisa é clara: mercados, governo e sociedade de todo o mundo devem se preparar para um planeta mais quente - não apenas $2^{\circ} \mathrm{C}$, mas $4{ }^{\circ} \mathrm{C}$ ou talvez até mesmo $6^{\circ} \mathrm{C}$ (PWC, 2012, p. 3).

A PwC dá como certo, portanto, o aumento de pelo menos $2^{\circ} \mathrm{C}$. Para entender o que isto representa, pode-se recorrer ao livro de Mark Lynas, "Seis Graus"50, premiado pela Royal Academy of London. Para redigi-lo, o autor, que é jornalista, fez uma vasta pesquisa em publicações científicas e traçou um cenário de como ficaria o planeta com a elevação média de seis graus na temperatura global. Assim, de acordo com ele, apenas $2^{\circ} \mathrm{C}$ a mais já seriam suficientes para o derretimento de todo o gelo da Groenlândia com drástica elevação do nível do mar. Se a temperatura continuar subindo, o cenário será apocalíptico. A elevação de $3^{\circ} \mathrm{C}$ faria o sistema terrestre atingir o "ponto sem volta" do aquecimento global, $4^{\circ} \mathrm{C}$ tornariam inabitáveis vastas regiões tropicais e subtropicais, $5^{\circ} \mathrm{C}$ poderiam fazer os oceanos expelirem metano e por fim o aumento de $6^{\circ} \mathrm{C}$ levaria à extinção mais de $95 \%$ das espécies do planeta. E é disto que a PwC está falando em seu relatório. Só que o alerta agora não parte de ambientalistas radicais, mas sim da voz do próprio mercado privado.

Volta-se então à questão: e o que as empresas pretendem fazer a respeito? Outro levantamento da PwC a respeito da opinião dos CEO's globais ${ }^{51}$ mostra que as questões ambientais não são consideradas prioritárias para este grupo de entrevistados. No relatório da de 2018, apenas 31 \% dos entrevistados (nona posição no ranking de ameaças) disseram estar preocupados com esta questão e sob a óptica dos possíveis impactos sobre seus negócios, enquanto as principais preocupações dos executivos foram o excesso de regulação estatal (42\%), o terrorismo (41\%), instabilidades geopolíticas $(40 \%)$ e ameaças virtuais (40\%). Na segmentação por região, a preocupação com as questões das mudanças climáticas sequer aparece no ranking dos líderes norte-americanos, enquanto no relatório de 2017, as questões ambientais nem chegaram a ser citadas.

O modelo analítico aqui proposto, elaborado a partir de estudos anteriores, permitiu a construção de uma proposta objetiva de análise e enquadramento de diversas categorias e indicadores objetivos de greenwashing, revelando a multiplicidade de formas, em seus diversos "tons de verde", com que são utilizadas pelas organizações.

Foi possível constatar que a estratégia de greenwashing utilizada pelos setores financeiro e automobilístico são diferentes. É possível supor que outros setores econômicos adotem formas distintas, o que justificaria estudos posteriores de recorte transversal. Também seria recomendável uma análise longitudinal aprofundada por empresa ou segmento capaz de identificar padrões e recorrências em tais estra-

50 Lynas, 2009.

51 PwC, 2018. 
tégias.

Além disso, a análise de algumas propagandas sugere que mudanças recentes no cenário político-ideológico e econômico podem sinalizar possível mudança na retórica publicitária em relação ao meio ambiente com uso de discursos ainda mais cínicos, ideológicos e desconectados com a gravidade da crise socioambiental.

\section{Conclusões}

A ocorrência do greenwashing no cenário da publicidade é uma realidade frequente e insidiosa. Há uma tendência de aumento na utilização de temas ambientais na propaganda, pois, além do oportunismo das empresas e da ressonância que seus discursos encontram junto às audiências, o fato é que as algumas organizações estão preocupadas com o futuro dos seus negócios, aos quais discricionariamente referem-se como "futuro do planeta". A utilização de um modelo metateórico para conceituar e identificar o greenwashing, como o proposto aqui, tenta contribuir para tornar mais objetiva a avaliação do que pode ou não incorrer neste tipo de violação ética.

Até o momento, no entanto, iniciativas muito fracas têm sido propostas para o controle do que se diz nas propagandas. Embora as mentiras que as organizações contam ao público em suas atividades publicitárias possam ser configuradas como crime contra o consumidor, passível de punição legal, no Brasil isto raramente tem acontecido. Por outro lado, a atuação de ONGs e grupos de defesa do direito do consumidor é difícil, uma vez que não há base legal ou jurisprudência sobre a questão do greenwashing, ou mesmo sequer uma boa compreensão sobre seu conceito e suas implicações. Neste sentido, também, a discussão de um modelo que esclareça e tipifique melhor o problema pode ser útil para a futura construção de um arcabouço legal mais específico.

É importante que exista uma base legal consolidada e bem fundamentada sobre a questão dos discursos das propagandas de forma geral, e da propaganda ambiental em específico não apenas para prevenir a ocorrência dos casos de greenwashing, mas para punir os casos comprovados, de forma a desestimular completamente este tipo de estratégia publicitária. Historicamente, a propaganda sempre encontra seus motes: da "geração saúde" dos anos 80, passando pela responsabilidade social e ambiental dos anos 90 até os apelos de sustentabilidade ao longo das primeiras décadas do século XXI. Talvez seja oportuno no processo de elaboração desta base legal, que se amplie e aprofunde o debate sobre o papel da propaganda em relação ao meio ambiente, ou acima de tudo, sobre qual é a relação que a sociedade pretende manter de fato com a natureza.

Uma alternativa possível, então, é por meio da construção de políticas públicas mais específicas e mais assertivas, capazes de coibirem os abusos. Isto, no entanto, só é possível se o agente público comungar dos mesmos valores éticos de comprometimento com a questão do meio ambiente e da proteção à vida. O que não tem sido o caso ao longo das últimas décadas. Ao contrário: o que se tem visto é um acirramen- 
to das disputas em torno das questões que envolvem o meio ambiente, um Estado internamente dividido, mas com uma franca orientação majoritária a pender para os lados que favorecem sempre o desenvolvimento econômico, ocasionalmente o social, e raramente o ambiental.

A ação popular poderia ser também uma alternativa, principalmente se ocorresse por meio de diversos instrumentos democráticos, diretos ou indiretos, como as iniciativas cidadãs ${ }^{52}$, petições, moções, referendos, plebiscitos, recalls políticos ${ }^{53}$, atuações diretas por meio de conselhos populares ${ }^{54}$ ou das chamadas "tecnologias cívicas" 55 .

No caso de assuntos que não contam com um clamor social tão forte, no entanto, isto é muito pouco provável que aconteça. Ao contrário: no atual cenário político e econômico em que o Brasil se encontra os apelos de consumo das propagandas em geral, e da propaganda verde especificamente, estabelecem ressonância com o comportamento do consumidor, e a "síndrome do consumo", criticada por Bauman ${ }^{56}$, está mais vigorosa do que nunca: consumir cada vez mais, mais rapidamente, com maior desperdício - e sem culpa.

$\mathrm{O}$ mercado sabe disto. E por causa disto tem claramente investido em vários tipos de estratégias que permitam uma melhoria no relacionamento com o cliente, por exemplo, buscando não apenas expor mais e melhor seus produtos e serviços às audiências, mas criar elos emocionais com o público, seja por meio da propaganda, seja proporcionando novas formas de comunicação, entretenimento e criação de experiências emocionais. E neste sentido, o greenwashing é uma excelente arma; afinal, filhotes de animais selvagens, belas imagens da vida marinha ou de paisagens naturais, associadas a uma boa direção de arte e a uma caprichada redação publicitária são capazes de vender qualquer coisa a qualquer um.

Se, mais do que vender, atividades promocionais como a propaganda e a publicidade conseguirem diminuir a dissonância cognitiva tranquilizando consumidores de que eles fizeram a melhor escolha para si, para o meio ambiente, a Terra e as futuras gerações, tanto melhor. Mas mais que isso: ainda é possível convencer o consumidor que dirigir um carro é expressão de liberdade e fazer cestos de lixo de origamis é bom para o planeta. Não se trata apenas de algum tipo de "licença poética" a que a propaganda se permite, mas sim, de uma reconstrução de conceitos e estilos de vidas.

O processo de mudança social para uma nova realidade passa pelo enfrentamento desta que aí está, de sociedade sujeitada e refém de forças proporcionalmente desiguais, a começar pelo reconhecimento da realidade e dos papéis desempenha- 
dos por cada um destes atores no cenário atual.

Especificamente, em relação à questão da propaganda ambiental, é necessário compreender o seu papel dentro da lógica do funcionamento dos mercados globais, e particularmente de seus efeitos negativos sobre a complexidade na qual estão inseridas indissociavelmente sociedade e natureza. Neste trabalho, apontamos que existe praticamente uma homogeneidade nos discursos das empresas em relação ao meio ambiente. Isto revela que todas elas estão alinhadas, e não com a preservação ambiental, mas com o modelo de reprodução de seus próprios negócios. Na verdade, estimulam e investem em um modelo que não seja estanque e monolítico, mas versátil e multiforme, capaz de se adaptar e de se reinventar perante as sucessivas crises que se apresentam, de forma a manter os padrões de produção e acumulação do ponto de vista sistêmico.

O debate a respeito de um novo modelo civilizatório que começou a partir da década de 1960, baseado em uma nova ética socioambiental, acabou em grande parte metabolizado e incorporado pelas forças de mercado, que tomaram contornos do próprio movimento ambientalista. Alguns chamam isso de "ética do mercado"57, mas talvez fosse mais apropriado chamá-la de "lógica dos lucros". Neste sentido, o desenvolvimento sustentável é um oximoro inviável tomado como mote pela publicidade e amplamente vendido como parte de uma nova identidade cultural rachada entre a necessidade de viver bem e o desejo de consumo infinito em bases materiais cada vez mais escassas e polarizadas.

A partir do histórico visto ao longo deste trabalho, o que se pode esperar é um acirramento das crises e conflitos relacionados ao modelo de desenvolvimento das sociedades atuais que buscam uma relação de dominação umas sobre as outras, e sobre o próprio meio ambiente. A ação de empresas e governos, por sua vez, se dá não por meio de propostas concretas de mudança, mas de políticas de adaptação e de lançamento de novos produtos e serviços com suas promessas publicitárias de ecoeficiência. Para o cidadão comum, continua sendo mais fácil, ainda que não menos custoso, comprar do que não comprar. E, enquanto os mercados vão ficando mais verdes, o futuro do meio ambiente parece, lamentavelmente, cada vez mais cinzento.

\section{Bibliografia}

AUER, Andreas. European Citizens' Initiative. European Constitutional Law Review no. 1, p. 79-86, 2005.

BAUMAN, Zygmunt. A Vida para o consumo: a transformação das pessoas em mercadoria. Rio de Janeiro: Jorge Zahar, 2008.

BRUNO, Kenny; KARLINER, Joshua. Earthsummit.biz: the corporate takeover of sustainable development. Canada: Institute for Food and Development Policy and Corpwatch, 2002.

57 Javalgi e Russell, 2018. 
BUTTS, D. How corporations hurt us all: saving our rights, democracy, institutions and our future. Victoria: Trafford Publishing, 2003.

CAVALCANTI, Clóvis. Concepções da economia ecológica: suas relações com a economia dominante e a economia ambiental. Revista de Estudos Avançados, São Paulo, v. 24, n. 68, p. 53-67, 2010.

CONLOGUE, Bill. Here and There: Reading Pennsylvania's Working Landscapes. University Park: Penn State Press, 2013.

CRONIN, Thomas E. Direct Democracy: The Politics of Initiative, Referendum, and Recall. Cambridge: Harvard University Press. 1999.

DELMAS, M.A. BURBANO, V. C. The drivers of greenwashing, California Management Review, no. 54, vol. 1, p. 64-87, 2011.

DOBRIN, Sidney I.; MOREY, Sean. Ecosee: Image, Rhetoric, Nature. Albany: State University of New York Press, 2009.

ÉPOCA. Revista edição 735. 18 jun 2012.

FAIRCLOUGH, N., WODAK, R. Critical Discourse Analysis. In: VAN DIJK,Teun A. (Ed). Discourse and social interaction. London: Sage, 1997.

FOLHA. Empresa decide suspender peça em todo o país. Folha Online. Agência Folha em Belo Horizonte. Publicado em 19 mar 2005. Disponível em http://wwwl.folha.uol. com.br/fsp/dinheiro/fil903200512.htm. [Consulta 30 nov 2012].

FT/IFC. Sustainable Financial Awards 2012. Criteria. Janeiro de 2012. <http://www. ftconferences.com/userfiles/file/SFA_2012_-_Criteria.pdf $>$. [Consulta 05 nov 12].

GILLSPIE, Ed. Stemming the tide of 'greenwash'. Consumer Policy Review; 18, 3; ABI/ INFORM Global, pg. 79, May/Jun 2008.

GILMAN, Hollie Russon. Civic Engagement and Civic Technology. American Political Science Association v. 50, n. 3, p. 741-743, 2017.

GOHN, Maria da Glória. Conselhos Populares e Participação Popular. Serviço Social e Sociedade, v. 9 n. 26, p. 25-47, São Paulo, Cortez, 1990.

HERMAN, Edward S., CHOMSKY, Noam. A manipulação do público: política e poder econômico no uso da mídia. São Paulo: Futura, 2003.

HOCH, D. FRANZ. R. Eco-pornography: False Environmental Advertising and How to Control It. Southeastern Journal of Legal Studies 1, 113-128, 1992.

JAVALGI, R. G.; RUSSELL, L. M. International Marketing Ethics: A Literature Review and Research Agenda. Journal of Business Ethics v. 148 no. 4, p. 703-720, 2018.

JOHN DEERE. Website institucional. Disponível em: <https://www.deere.com.br>. [Consulta $10 \mathrm{dez} 2018$ ].

KARLINER, Joshua. The Corporate Planet: Ecology and Politics in the Age of Globalization, San Francisco: Sierra Club Books, 1997.

LAYARGUES, Philippe. A cortina de fumaça. São Paulo: Annablume, 1998.

LYNAS, Mark. Seis Graus. Rio de Janeiro: Zahar. 2009.

LYON T., MAXWELL J. Greenwash: Corporate environmental disclosure under threat of audit. Journal of Economics and Management Strategy, no. 20, p. 3-41, 2011.

LYON, Thomas P.; MONTGOMERY, A. Wren. The Means and End of Greenwash. Organization \& Environment vol. 28, no. 2, p. 223 - 249, 2015.

MCCHESNEY, Robert W. Global media, neoliberalism, and imperialism. Monthly Review no. 52, vol. 10; Alt-Press Watch (APW), 2001. 
MUNSHI; D. KURIAN, P. Imperializing spin cycles: A postcolonial look at public relations, greenwashing, and the separation of publics. Public Relations Review, vol. 31, no. 4, p. 513-520, 2005.

PAGOTTO, Erico Luciano; CARVALHO, Marcos Bernardino; MEYER, Gustavo Costa. Ideologia, memória coletiva e fetichização na construção social do mito da sustentabilidade. In: Diamantino Pereira. (Org.). Mudança Social e Participação Política: estudos e ações transdisciplinares. São Paulo: Annablume, p. 25-40, 2017.

PEARSE, Guy. Greenwash: Big Brands and Carbon Scams. Collingwood, Vic.: Black Inc., 2012.

PEIXOTO, Paulo. Justiça veta comercial da Volkswagen na TV. Folha Online. $<$ http:// wwwl.folha.uol.com.br/fsp/dinheiro/fi1903200511.htm>. Publicado em 19 mar 2005. [Consulta 30 nov 2012].

PWC. 21st CEO Survey - The Anxious Optimist in the Corner Office.

PricewaterhouseCoopers, 2018. Disponível em <https://www.pwc.com/>. [Consulta 01 mai 2018].

PWC. Too late for two degrees? Low Carbon Economy Index 2012. PricewaterhouseCoopers, 2012. <https://www.pwc.com/>. [Consulta 01 mai 2018].

ROCHA, Maria Eduarda M. A nova retórica do capital: a publicidade brasileira em tempos neoliberais. São Paulo: Editora USP, 2010.

ROWELL, A. The Spread of Greenwash. In: LUBBERS, E. Battling big business: countering greenwashing, infiltration, and other forms of corporate bullying. Monroe: Common Courage Press, 2002.

SANTOS, Denise Azevedo. Propaganda, consumo e sustentabilidade: uma análise narrativa da publicidade como aporte à educação ambiental crítica. 140 p. Dissertação. Programa de Pós-Graduação Stricto Sensu em Ensino de Ciências, Instituto Federal de Educação, Ciência e Tecnologia do Rio de Janeiro (IFRJ), Nilópolis, RJ, 2011.

SIANO, Alfonso, VOLLERO, Agostino, CONTE, Francesca, AMABILE, Sara. "More than words": Expanding the taxonomy of greenwashing after the Volkswagen scandal. Journal of Business Research, vol. 71, p. 27-37, 2017.

SOUZA SANTOS, Boaventura. Os perigos da desordem jurídica no Brasil. In. PRONER, Carol; CITTADINO, Gisele; TENENBAUM, Marcio; RAMOS FILHO, Wilson. A resistência ao golpe de 2016. São Paulo: Projeto Editorial Práxis, 2016, p. 131-132.

VALOR ECONÔMICO. Os 100 maiores bancos. <http://www.valor.com.br/valorl000/2017/ ranking100maioresbancos>. [Consulta 01 mai 2018].

VEIGA, José Eli da. Indicadores de sustentabilidade. Estudos Avançados, São Paulo, v. 24, n. 68, p. 39-52, 2010.

(c) Copyright: Pagotto Érico y Bernardino de Carvalho Marcos, 2020

(c) Copyright: Scripta Nova, 2020.

Ficha bibliográfica:

PAGOTTO Érico y BERNARDINO DE CARVALHO Marcos. Natureza à venda: da ecopornografia a um modelo compreensivo de indicadores de greenwashing. Scripta Nova. Revista Electrónica de Geografía y Ciencias Sociales. Barcelona: Universidad de Barcelona, 1 de febrero de 2020, vol. XXIV, $n^{0}$ 631. [ISSN: 1138-9788] 